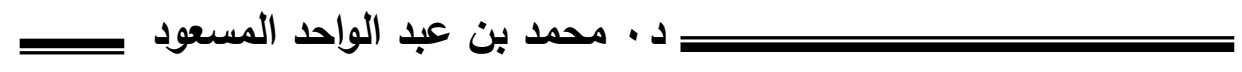

\title{
النزعة الإنسانية
}

\section{في الشعر السعودي المعاصر}

د. ال. محمد بن عبد الواحد المسعود (*)

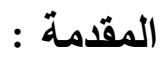

أولا: أهمية الموضوع، وأسباب اختياره:

الحمد لله رب العالمين، والصلاة والسلام على أثشرف الأنبياء والمرسلين، نبينا

محمد وعلى آله وصحبه أجمعين، أما بعد:

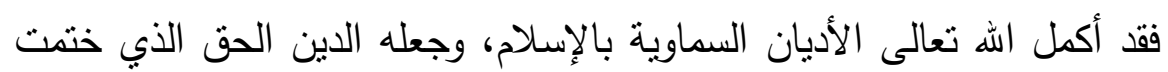

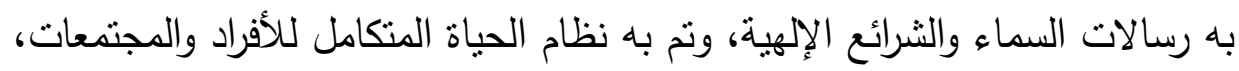

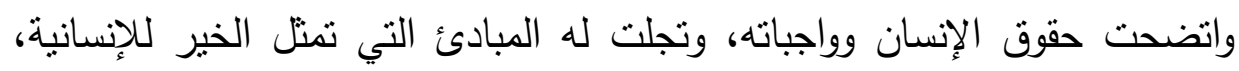

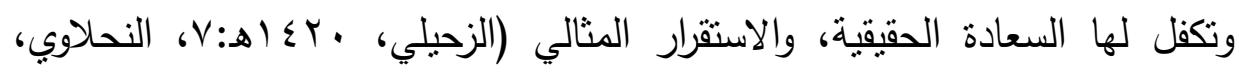

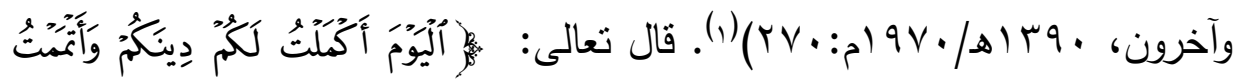

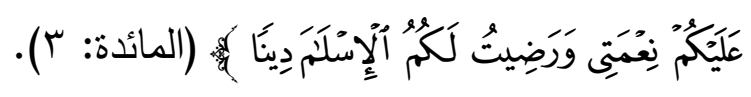

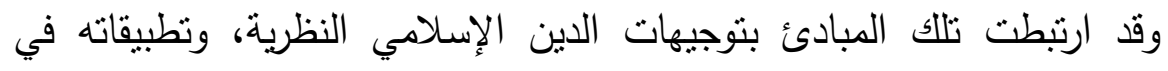

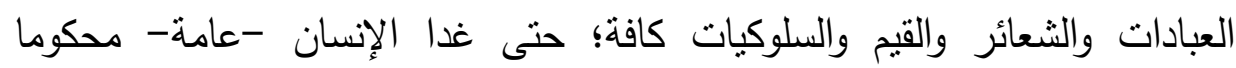

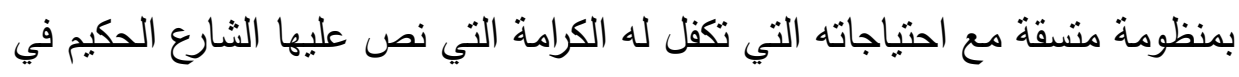

الأستاذ المساعد في جامعة الإمام محمد بن سعود الإسلامية - كلية اللغة العربية -

$$
\text { قسم الأدب -الرياض - الملكة العربية السعودية. }
$$

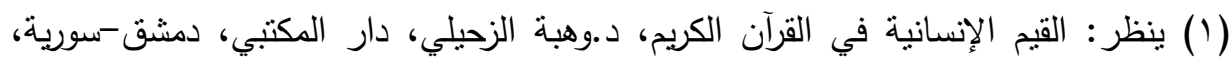

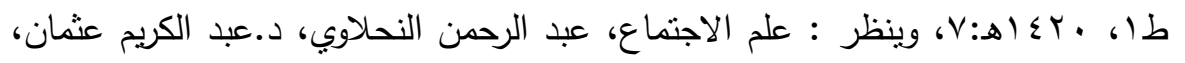

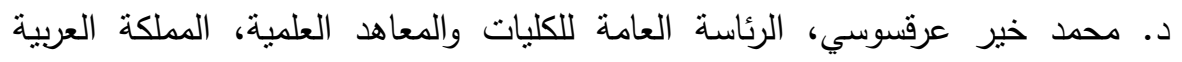

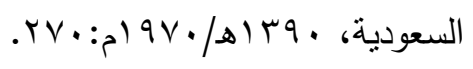




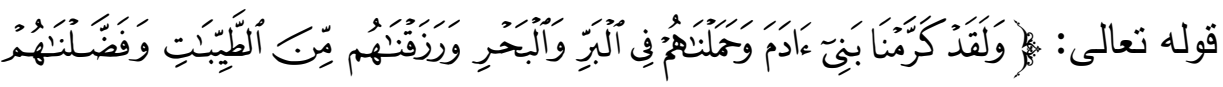

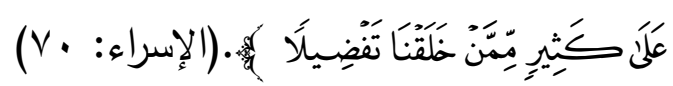

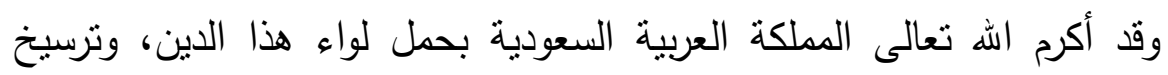

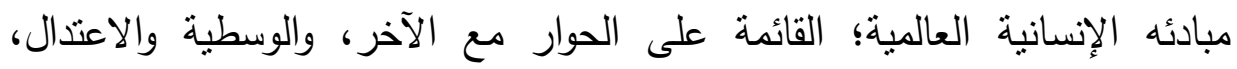

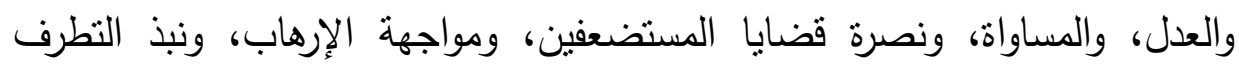

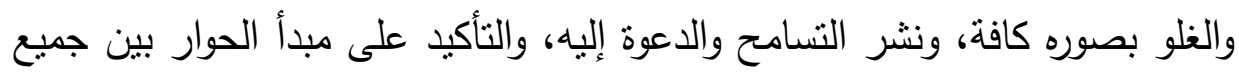
الثقافات، وتحقيق الإخاء الإنساني، واحترام الحضارات الأخرى.

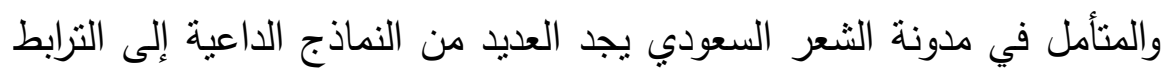

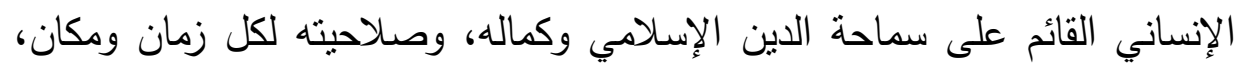

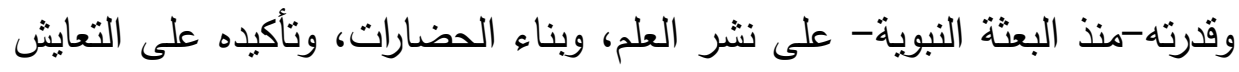

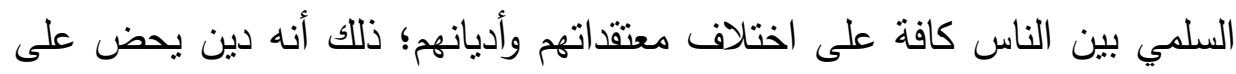

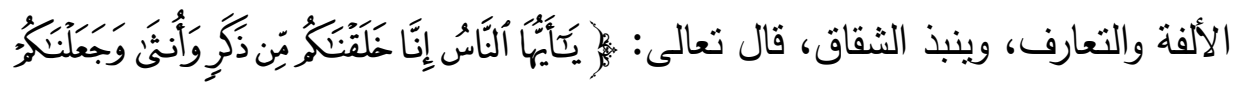

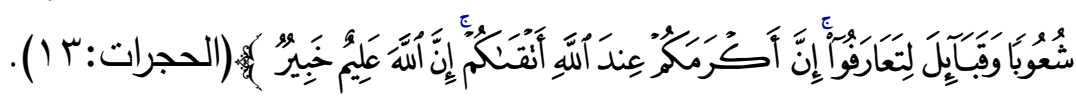

\section{ويمكن اختزال أسباب اختيار موضوع البحث في النقاط الآتية:}

ا-بيان الصورة الحقيقية للإسلام القائمة على التنسامح، والتعايش الإنساني، وقبول الآخر ، وحوار الحضارات والثقافات.

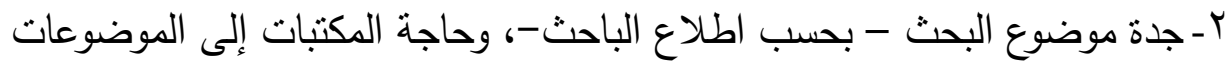
التي لم تدرس، ولم تتل اهتمام الباحثين المتخصصين.

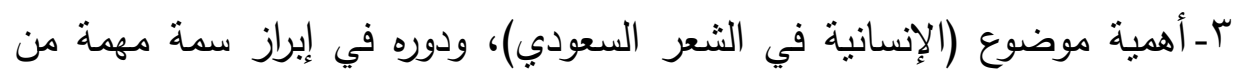

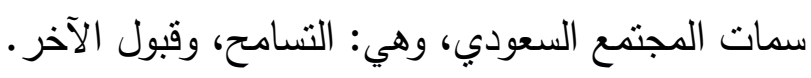
ع-بيان دور الثعر السعودي في كثف الدكونات الثقافية للمجتمع السعودي؛ المستمدة من كتاب الله تعالى وسنة النبي -صلى الله عليه وسلم- وفق فهم السلف لهن 


\section{دـ · محمد بن عبد الواحد المسعود}

0-وجود مدونة شعرية كبيرة تجلي موضوع (الإنسانية في الشعر السعودي)، وتسهم في الرد على أكاذيب أعداء المملكة العربية السعودية، وتبين زيفهر وكذبهم. 7-خدمة الشعر السعودي، وإبراز سماته من خلال دراسة موضوع مهم من

$$
\text { ثانيا: أهداف البحثاته، وهو (الإنسانية)، وما بندرج تحته من موضوعات صغرى. }
$$

1 - تجلية الصورة الحقيقية للمملكة العربية السعودية (حكومة وشعبا)؛ القائمة على قيم:

$$
\text { التسامح والوسطية والاعتدال في التعامل مع الحضارات والثقافات المتتوعة. }
$$

r-كثف الموقف الإنساني للمواطن السعودي ـالثعراء أنموذجا-من القضايا

$$
\text { العالمية، ونصرة المستضعفين. }
$$

זـ التأكيد على موقف الثاعر السعودي؛ الرافض للإزهاب والنطرف والغلو والنتدد والقتل والدمار بأنشكاله كافة.

ع- دراسة الموضوعات التي تنين جهود المملكة العربية السعودية في مكافحة الإرهاب

$$
\text { والغلو والنطرف. }
$$

○-بيان الآليات الفنية التي أفاد منها الشعراء السعوديون؛ لبيان المواقف الإنسانية

$$
\text { للمملكة العربية السعودية حكومة وشعبا. }
$$

إ-إبراز سمة من سمات الشعر السعودي، وهي: الجمع بين المتعة الفنية، والمنفعة

$$
\text { المضمونية. }
$$

ثالثا: منهج البحث:

يقارب البحث النزعة الإنسانية عن الثاعر السعودي، وفق المنهج الموضوعاتي لسبر أغوارها، وذلك بالانطلاق من قراءة الموضوعات (الثيمات) الصغرى له، وتجلياتها الفنية المتكررة؛ لكثف موقف الثناعر السعودي من الإنسان عامة، وما تحمله تللك النظرة من مرتكزات إنسانية إسلامية قائمة على الوسطية، والحوار بين التقافات والحضارات المتعددة بوصفها تتوعات لا تتاقضات، وتقبل الآخر، ونبذ العنف والتتدد والغلو والتطرف، ورفض الحروب والنزاعات تحت أية 
ذريعة من الذرائع، مع التأكيد على نصرة قضايا المستضعفين، ونشر الأمن والسلام

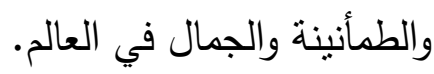

رابعا: أبرز المعوقات والصعويات في سبيل إنجاز البحث:

1 - تعدد مفاهيم (الإنسانية) في الدراسات والبحوث، وحاجته إلى التحديد الدقيق.

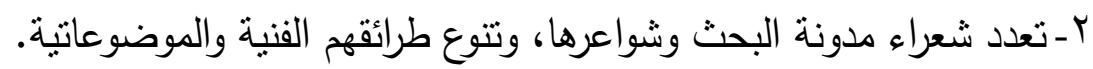

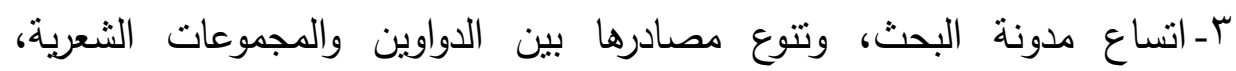

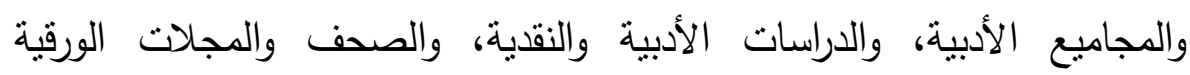

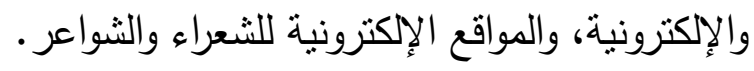

خامسا: خطة البحث:

وزعت البحث في مقدمة، وتمهيد، وأربعة مباحث، وخاتمة؛ وفق ما يأتى:

المقدمة:

تتضمن تعريفا بموضوع البحث، وأهميته، وأسباب اختياره، وأهدافه، ومنهج البحث، وأبرز المعوقات والصعوبات في سبيل إنجازه، وخطته.

التمهيل: مفهوم النزعة الإنسانية في الإسلام وأهميتها:

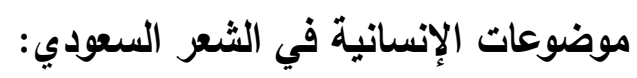
المبحث الأول: الإنسانية / النسامح. المبحث الثاني: الإنسانية / المساواة.

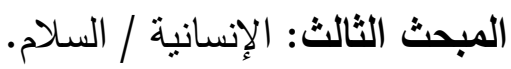

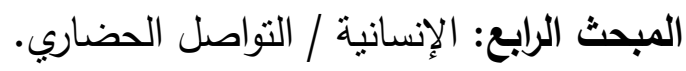
الخاتمة:

سيدون فيها الباحث أبرز النتائج التي توصلت إليها الدراسة، كما سيذكر أبرز التوصيات التي يراها من خلال معايشته للبحث. فهرس الموضوعات: سيمرر فيه الباحث عناوين أقسام البحث، وصفحاتها. 


\section{التمهـيد}

\section{مفهوم التزعة الإنسانية، وأهميتها}

الإسلام دين إنساني عام، يخاطب الأمم كافة دون تفريق بين أمة وأمة بفارق الإساله

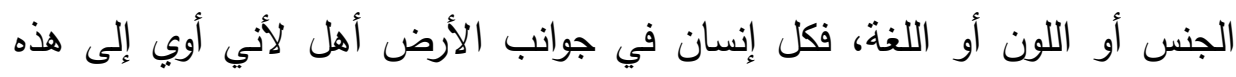

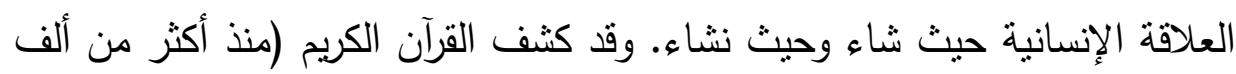

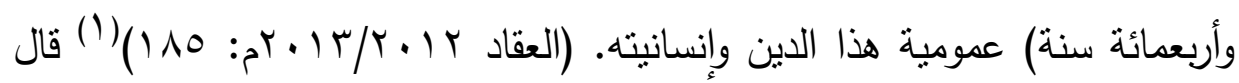

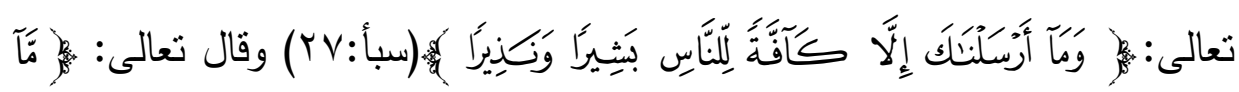

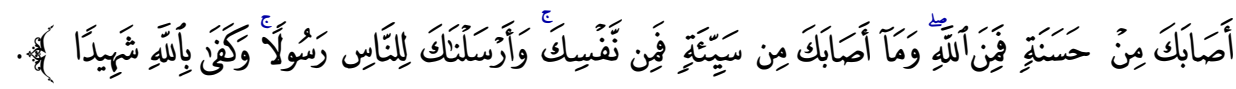

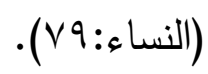

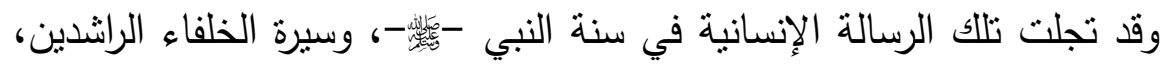

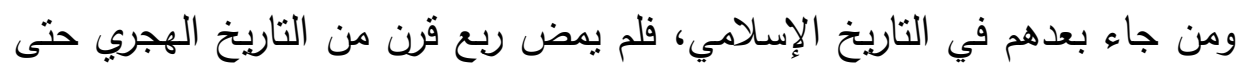

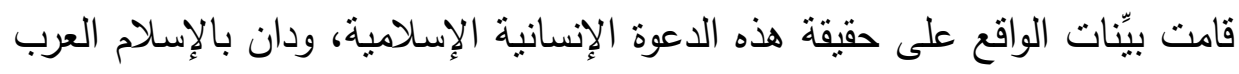

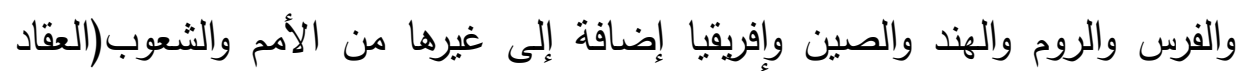

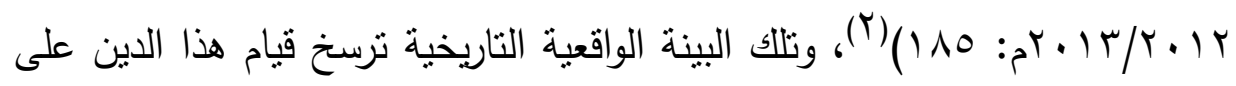
النواصل الإنساني وقبول الآخر ، وتعزيز وسائل الحوار الحضاري والثقافي معاه، وتؤكد

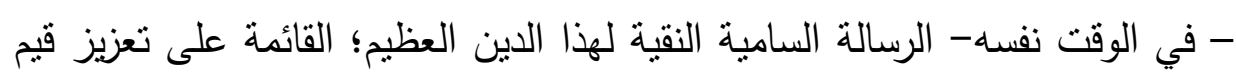

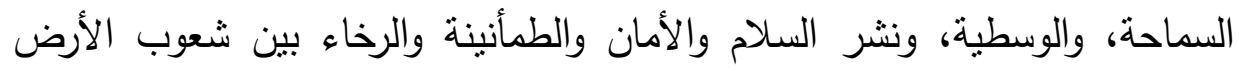

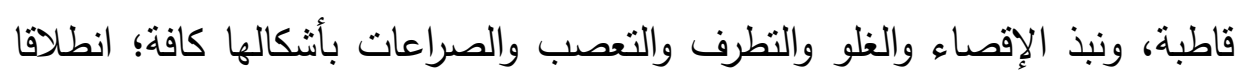

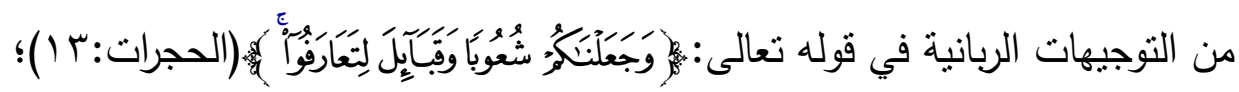

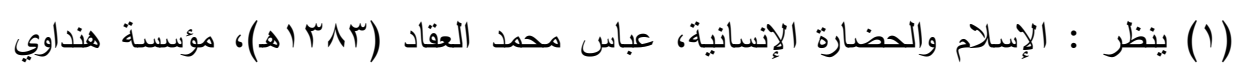

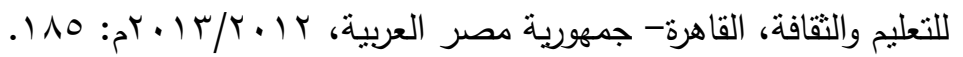
(r) ينظر : الإسلام والحضارة الإنسانية: 110. 


\section{النزعة الإنسانية}

من أجل حياة إنسانية قائمة على إنهاء النزاعات والفتن، وتعزيز السلام والأمن والأمان في الأرض، من أجل عمارتها، وبناء حضارة إنسانية قوامها توفير حياة كريمة أنهاء للإنسان.

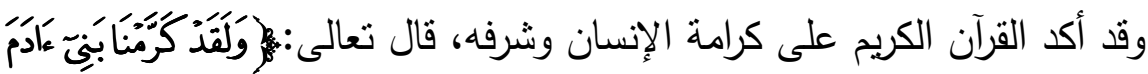

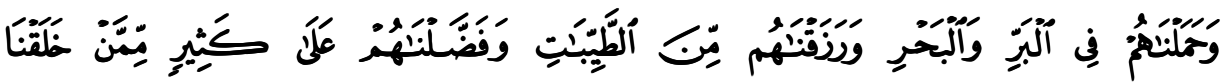

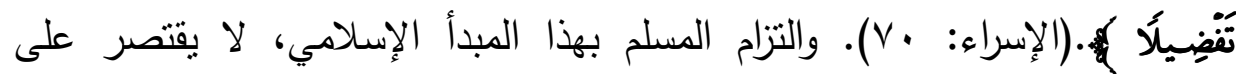

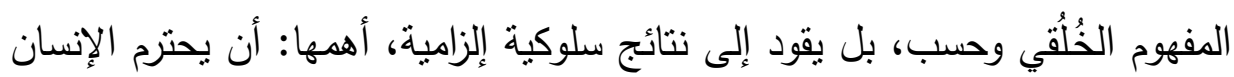

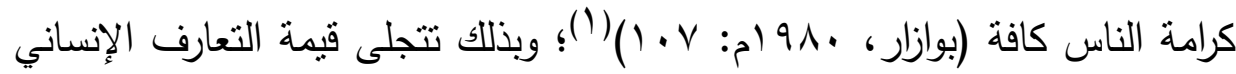

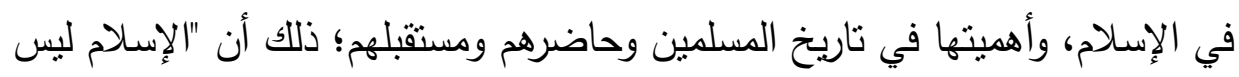

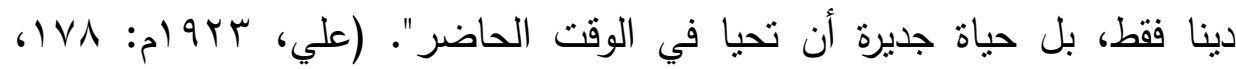

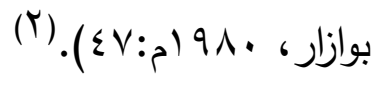

وتبرز في المجتمع المسلم جملة من القيم؛ التي نعزز النزوع الإنساني في

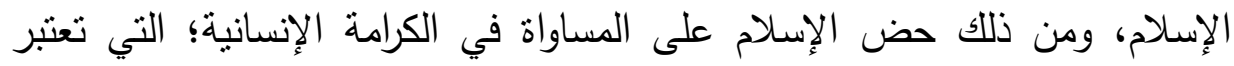

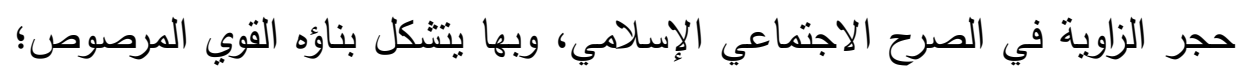

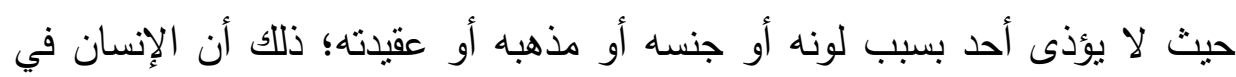

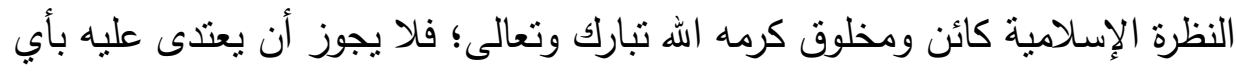

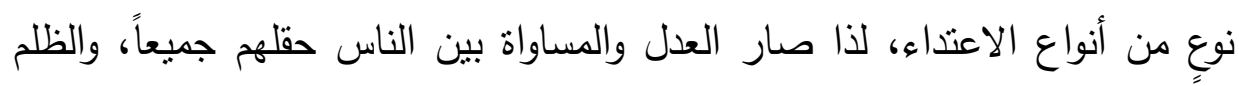

(1) ينظر : إنسانية الإسلام، مارسيل بوازار، ترجمة: د.عفيف دمثقية، دار الآداب بيروت،

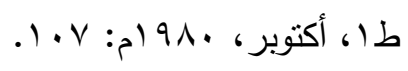

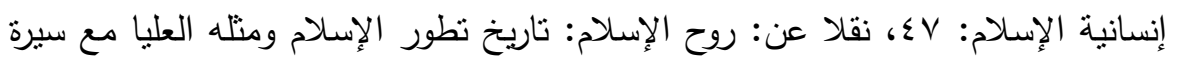

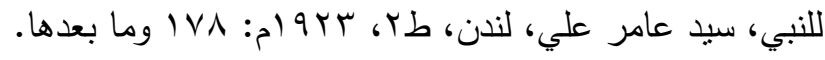

$$
\begin{aligned}
& -1 \cdot \varepsilon-
\end{aligned}
$$




\section{د. • محمد بن عبد الواحد المسعود}

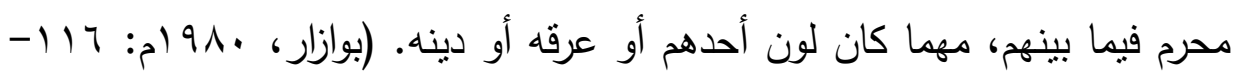

$$
\text { (1) }
$$

وقد أثبت التاريخ كيف بنى الإسلام مجتمعا متتاسقا مندمجا دون تفرقة طبقية أو مذهبية أو دينية أو جنسية؛ لذا تميز المجتمع المسلم عبر التاريخ بقيامه على التعايش الاجتماعي والعرقي والديني، وخلوه - في الوقت نفسه - من الصدامات والصراعات؛ حيث أناح للشعوب التي فتح بلادها حربة الانتماء الديني ضمن إطار معاهدة الحماية(الذمة)؛ التي ينال بموجبها غير المسلم الأمان على أشخاصهم وأرزاقهم، مع بع الاعتراف بحقوقهم الأخلاقية والمدنية والعامة، مقابل دفع مبلغ مالي، مع الامتتاع عن الأعمال التي تضر بسلامة المجتمع، أو التعاليم الإسلامية. ويتميز ذلك العهد/الميثاق ولئ

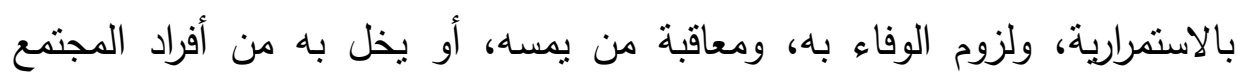
المسلم، مع التأكيد على أن إخلال أحد المعاهدين لا يؤدي إلى قطع منافع المعاهدة عن بقية المعاهدين، وبذللك تكون المعاهدة تعبيرا عمليا عن التسامح الإسلامي؛ الذي إي يسمح باستقبال شعوب من ديانات متتوعة، ويمنحهم حق الإقامة في العالم الإسلامي، مع الاحتفاظ بدينهم، وحمايته من الأخطار الداخلية أو الخارجية، والدفاع عنهم، وصيانة مصالحهم وأرزاقهم وممتلكاتهم، وضمان حقوقهم وحرياتهم الملكية والتجارية

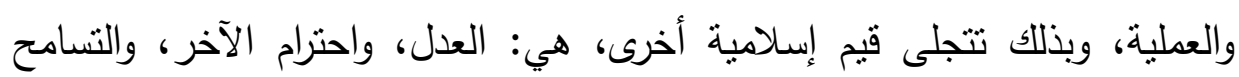

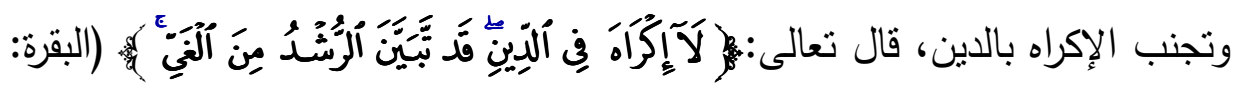

(1) ينظر : إنسانية الإسلام: 117-1/T. وينظر : القيم الإنسانية في الإسلام (ورقة بحثية مقدمة إلى الندوة الدولية: "التعايش السلمي في الإسـلام "المنعقدة في (كولومبو) في الإلي الإنها

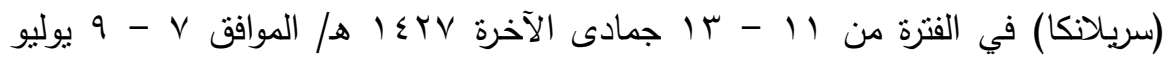

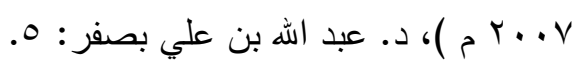




\section{النزعة الإنسانية}

ولم يتوقف التسامح الإنساني في الإسلام عند ذلك وحسب، فقد أظهر الإسلام من الوجهة التاريخية والسياسية تقديرا لغير المسلمين؛ ومن ذلك الإبقاء على مؤسسات الإنات

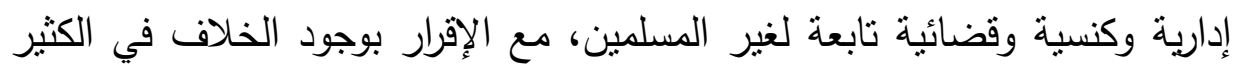

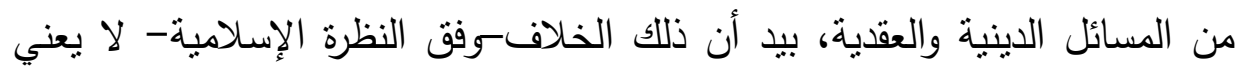

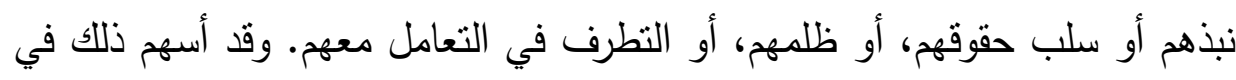

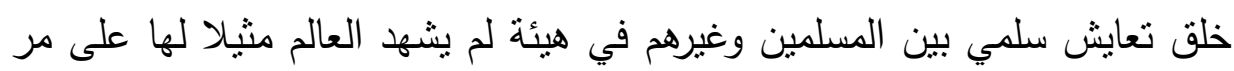

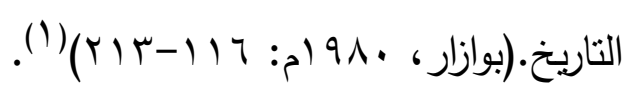

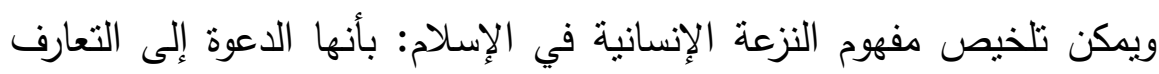

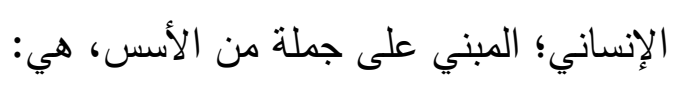

- نساوي البشر في الإنسانية، وطبيعة الخلق العامة.

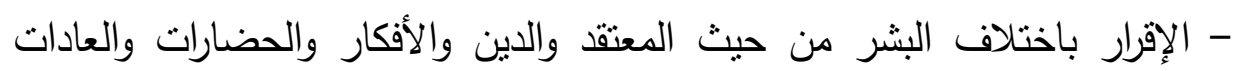
والثقاليد.

- الالتزام بقيم الإخاء الآدمي، والتعاطف الإنساني، والتعاون في الدصائب، ونشر

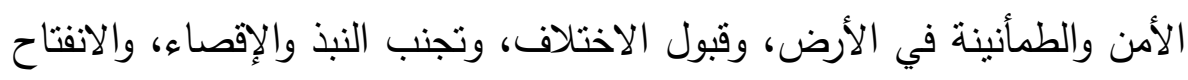

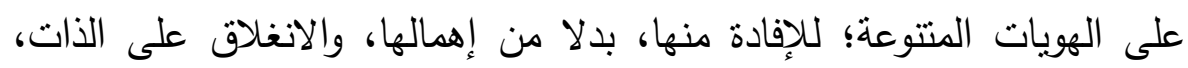
والحث على أسباب الجمال والسكون والسلام، ورفض التطرف والتتدد والقتل

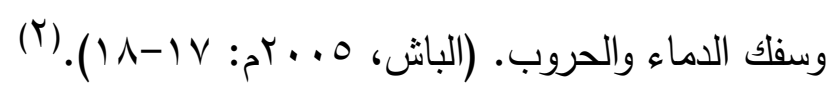

وبتكامل تلك الأسس يتحقق التعارف الإنساني في الإسلام؛ الوارد في قوله

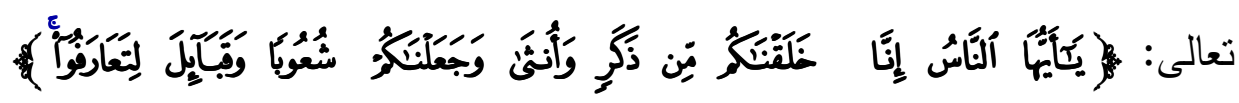

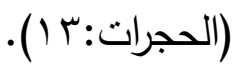

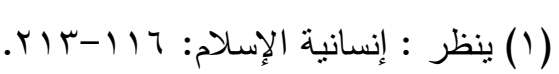

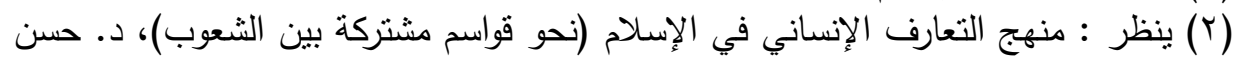

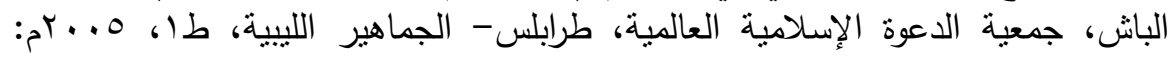




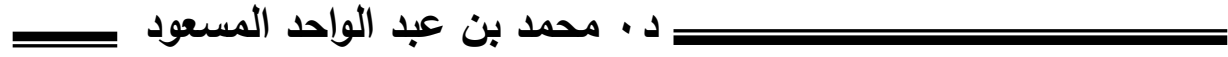

\section{المبحث الأول}

$$
\text { الإنسانية - التسامح }
$$

أقرت الثريعة الإسلامية اختلاف الناس في المعتقدات والمبادئ والقيم والعادات والتقاليد، ودعت إلى التسامح، وقبول الآخر ، واطراح فكرة تصادم الأفكار والمعتقدات، وتتاحر القيم والعادات، ونبذتفي الوقت نفسه-التتدد والتطرف والعداء والإقصاء بأشكاله كافة؛ ذلك أن الاختلاف بين الناس اختلاف تتوع لا اختلاف تضاد أو صراع.

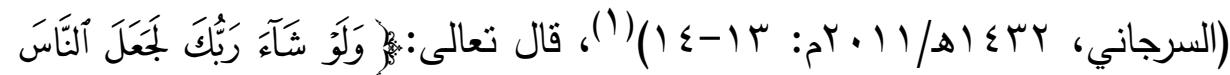

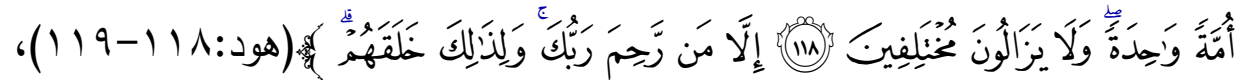

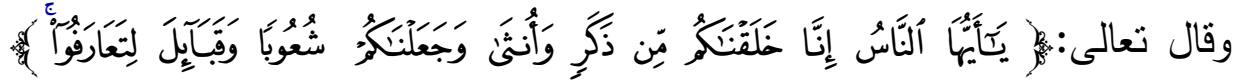

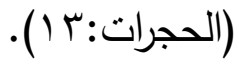

وإذا تتبعنا الثعر السعودي في أطواره الأدبية المختلفة، نجده يرسخ تلك النزعة الإنسانية للإسلام، ويكرر العديد من موضوعاتها، ومن ذللك موضوع التسامح؛ الذي كثف عن حرص الثاعر السعودي على تعزيز العلاقات الإنسانية بين البشر، ودعم الحوار بين الثقافات المتعددة والحضارات المتتوعة بوصفها تتوعات لا تتاقضات، وون نماذج ذللك قول حسين عرب في مديح الرسول- -

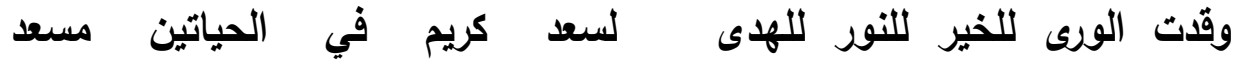

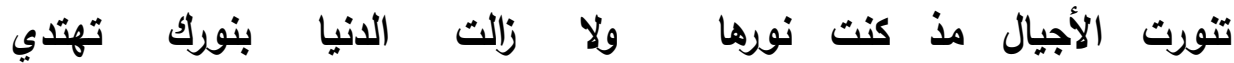

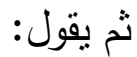
(1) ينظر : المشترك الإنساني - نظرية جديدة للتقارب بين الثعوب-، أ.د. راغب السرجاني،

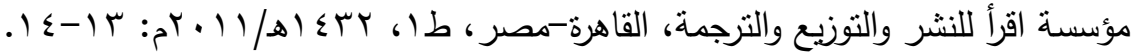




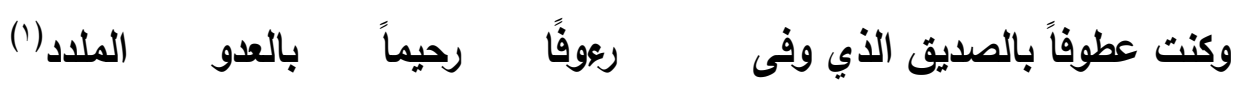
ترسخ الأبيات السالفة سماحة الرسالة المحدية، وشمولية رحمتها. (ابن النائ)

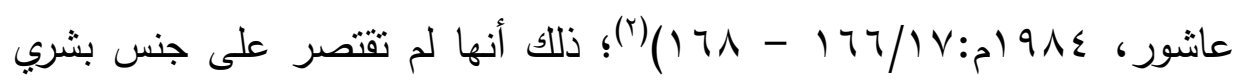

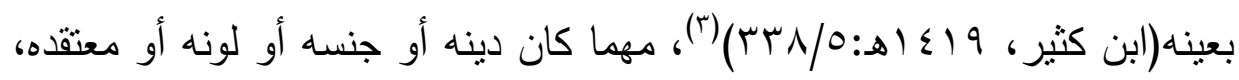

(1) مكتي قبلتي-شعر وشعراء-، إعداد أحمد قنديل(99 (1اهـ)، دار الرفاعي، طا،

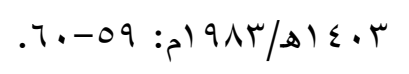

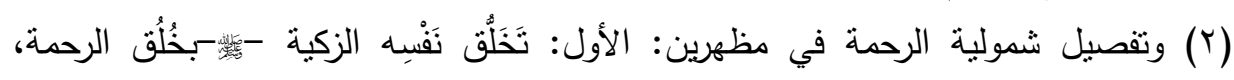

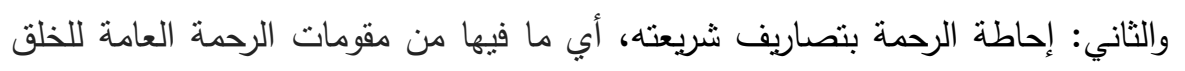

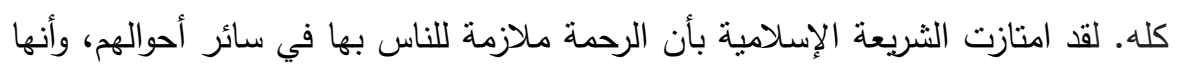

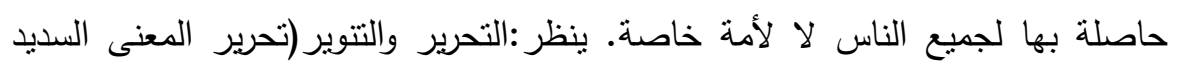

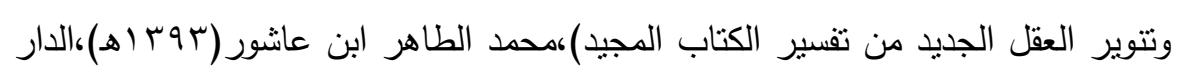

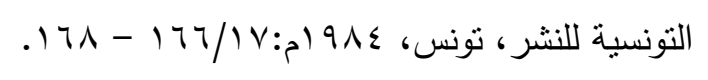

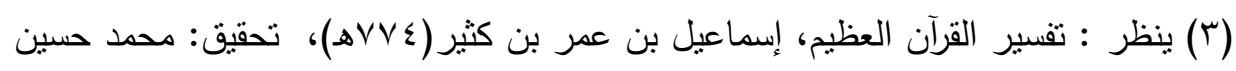

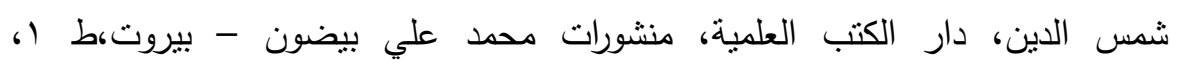

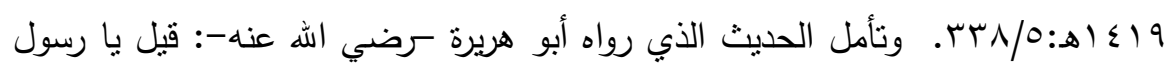

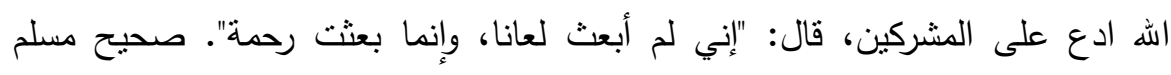

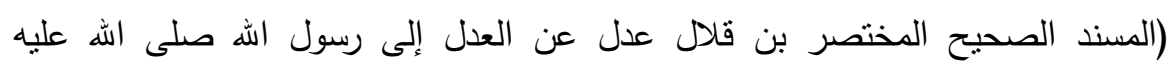

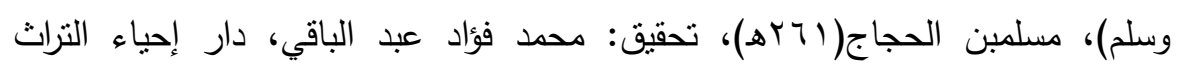

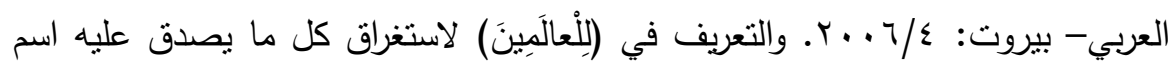

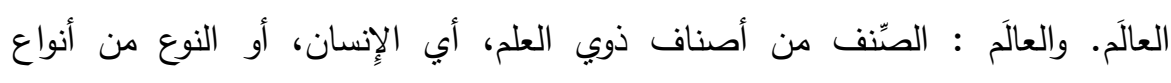

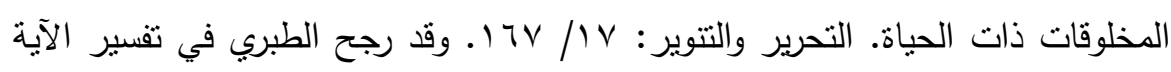

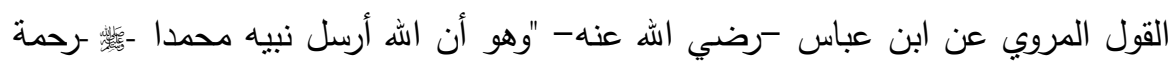

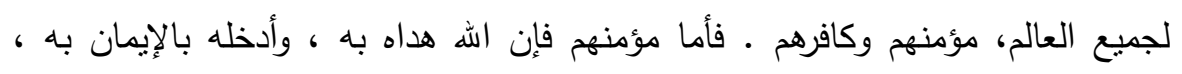

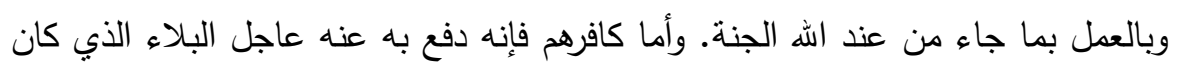

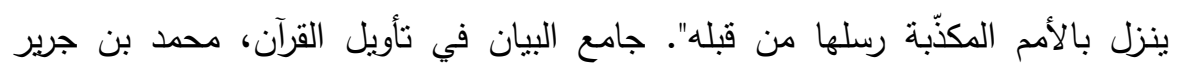

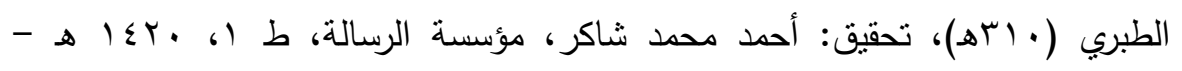

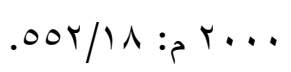




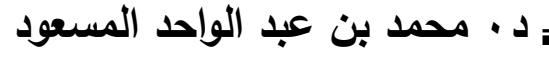

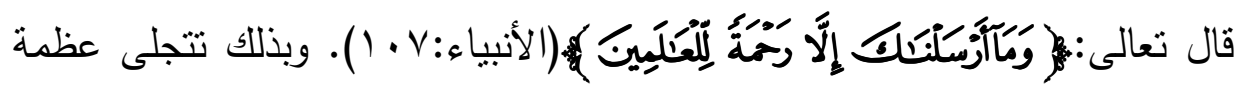
الإسلام، وإنسانيته؛ المتسمة بالتسامح مع الآخر، والحرص على نشر الخير في

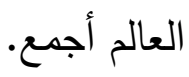

وقد وظف حسين عرب المعجم اللغوي لترسيخ موضوع التسامح، ومن ذللك

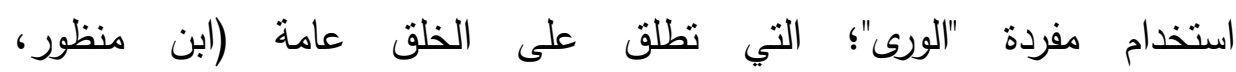

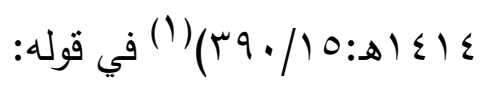

وقدت الونى للخير للنور للهوى ل ل فالرسول عليه الصلاة والسلام -كما أسلفت -هو قائد الخلق قاطبة إلى أسباب الخير والنجاح، وذلك يكرس نزوع الإسلام إلى التسامح، وتعزيز المشتركات الإنسانية

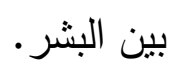

ومن النماذج -أيضا- قصيدة:"فرية الثمطاء" للدكتور : فواز اللعبون؛ التي رفض فيها ربط الإسلام بالعنف والقتل والإرهاب، وأكد -في الوقت نفسه - سماحة الإسلام ووسطيته وإنسانيته. يقول اللعبون:

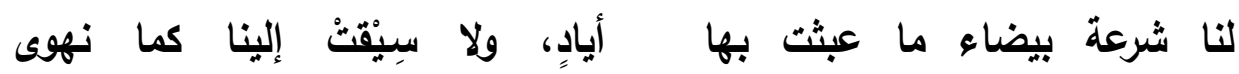

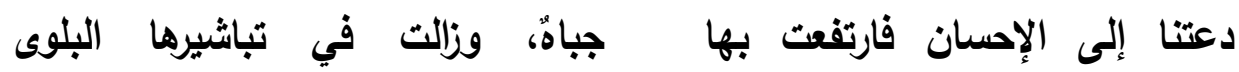

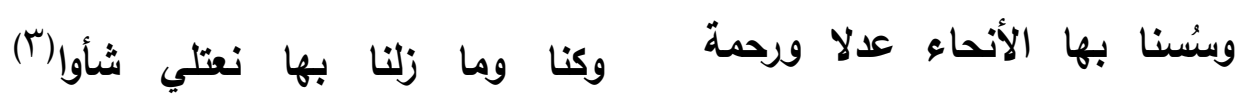
(1) ينظر : لسان العرب، محمد بن مكرم بن علي ابن منظور (I/ (Yه)، دار صادر، بيروت،

$$
\text { ط ط }
$$

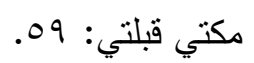

(r) قصيدة مخطوطة مرسلة من الثاعر • ومن النماذج: قصيدة :"الموت بالمجان" لأبي الفرج عسيلان؛ ينظر : باتجاه الثمس، أبو الفرج عبد الرحيم عسيلان، نادي المدينة المنورة

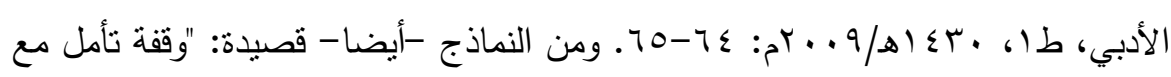
نهاية العام" لعائض الثبيتي. ينظر : عزف القوافي، عائض مستور الثبيتي، النادي الأدبي

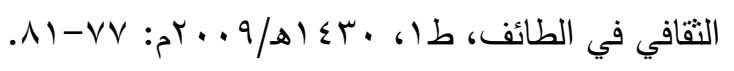




\section{النزعة الإنسانية}

وقد عمد بعض الشعراء إلى تخصيص موضوع التسامح بجعله مرادفا لموضوع الإع

نبذ الإرهاب كما في قصيدة: "على لسان إرهابي تائب" لأحمد السالم، يقول فيها:

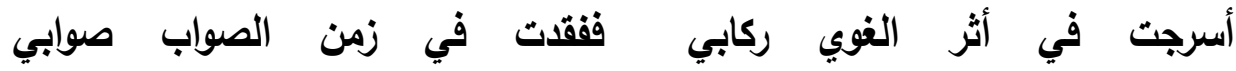

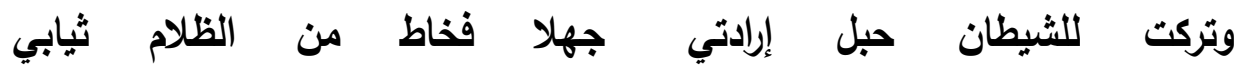

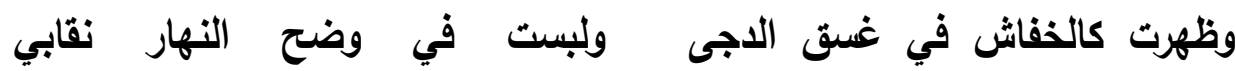

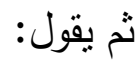

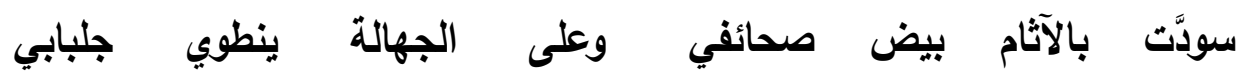

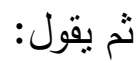

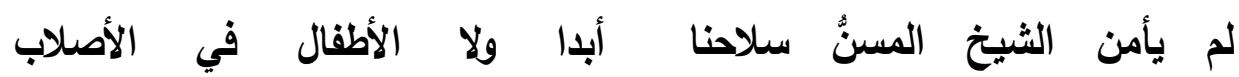

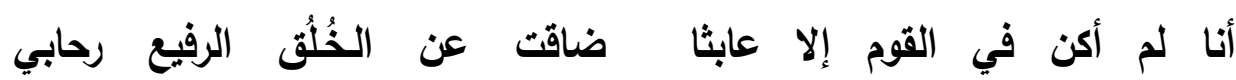

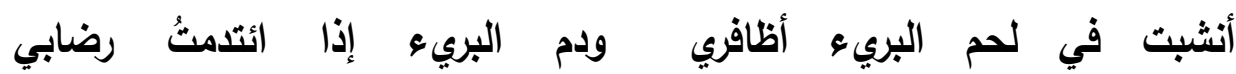

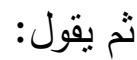

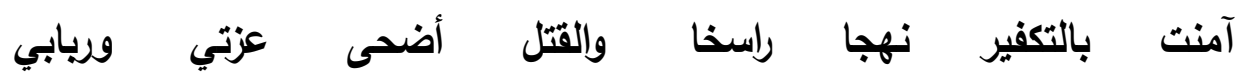

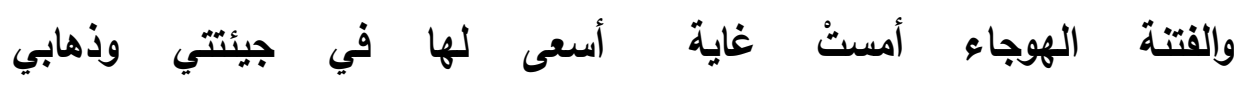

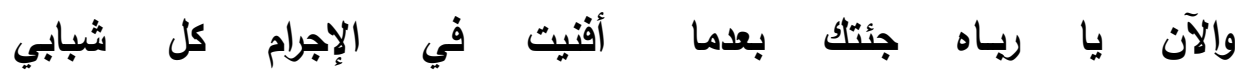

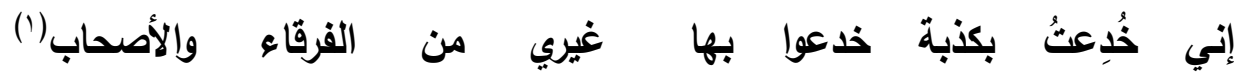

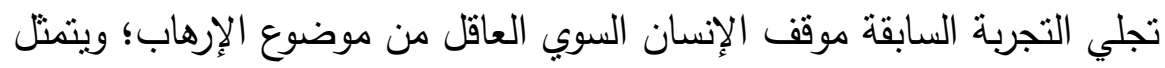
ذلك الموقف في رفض الإرهاب فكرا وسلوكا؛ ذلك أنه يتتاقض والمبادئ الإنسانية

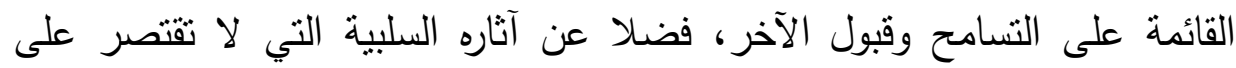
الجانب المادي المحسوس (التقجير - القتل مثلا)، بل تمند التقوض القيم الفاضلة

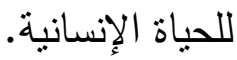

قبلات على الرمل والحجر، د. أحمد بن عبد الله السالم، هبة النيل العربية للنشر والتوزيع

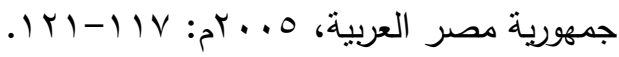




\section{دـ د · محمد بن عبد الواحد المسعود}

وقد جلى الثاعر تلك الحقيقة بحركية موضوع التسامح وتفاعله مع جملة من الموضوعات الصغرى المنفرة من الإرهاب، وهي: التطرف - القسوة- الجهل - الغواية -الحمق - السفه والطيش- الخداع- المكر - الكنب - النفاق - النذليس - الظلم سوء العاقبة - الخيانة. وقد أفادت تلك الحركية الموضوعاتية من أسلوب الموازنة العقلية (خارج إطار النص) بين موضوعين اثثين: 1 ـ الإرهاب، وتمثله حياة الإرهابي قبل التوبة. r التسامح / نبذ الإرهاب، وتمثله حياة الإرهابي بعد التوبة. فصار موضوع نبذ الإرهاب سبتلك الموازنة العقلية -قسمي الموضوع التسامح، ومخصصا له، ومتوائما مع الفطرة الإنسانية الإسلامية. أما الإرهاب فمناقض لذلك كله.ومن نماذج المقارنة العقلية -أيضا- قصيدة:"الإرهاب"الحمد محمد حكمي:

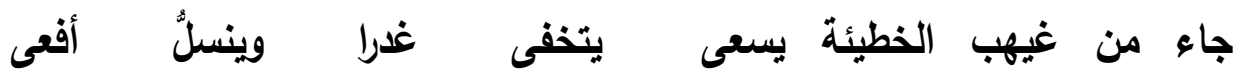

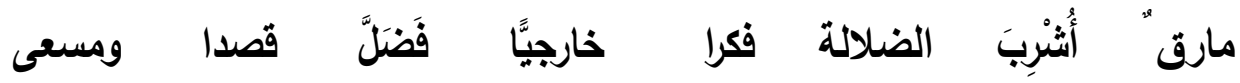

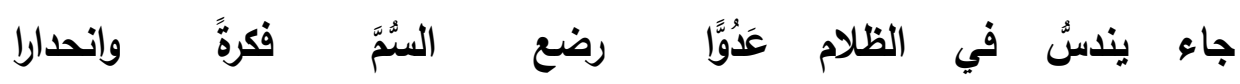

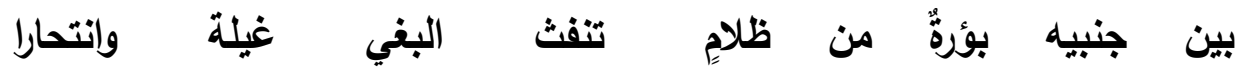

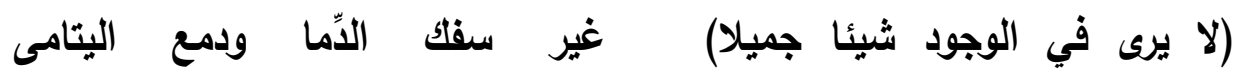

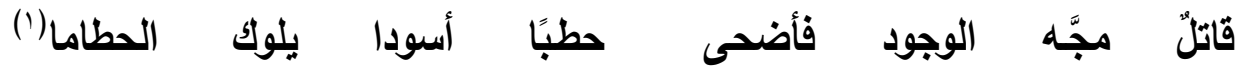
تفاعلت موضوعاتية الإرهاب مع جملة من الموضوعات الصغرى، أهمها: الظلمة- التخفي - الخديعة - ضلال الفكر والمنهج والغاية - الاعتداء - تزبيف الحقائق - القتل - سفلك الدماء. وقد أسهر ذلك في تجلية حقيقة الإرهاب وأثزه السلبي في العالم أجمع، إضافة إلى الترغيب في التسامح وقبول الآخر، من خلال المقارنة العقلية بينهما كما أسلفت في نص د. السالم. ومن النماذج -أيضا- قصيدة: "أيدي

إجهاشة النبض، حمد بن محمد علا الله حكمي، نادي جازان الأدبي، طا، 
التطرف"(1) لفوزية الجهني، وقصيدة: "وجدان... وشظايا الإرهاب!!"(كال) العبد اله الحميد.

وقد يتماهى موضوع التسامح مع موضوع نشر الخير والسلام، ومن نماذج ذلك قصيدة:"أنا" للثاعر حمد الزيد. ومنها: ملأت فؤداي

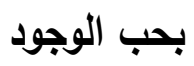

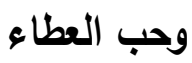

وكنت كما البذر تنشره الريح

هنا أو هناك

فيمرع للآخرين

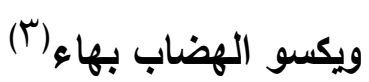

وخلاصة القول : إن موضوع التسامح كثف عن نزعة إنسانية لاى الثعراء السعوديين، مع تتوع تجليات ذلك؛ فتارة بستتد الموضوع على موضوعات ذات ذات أبعاد دينية، كما فعل حسين عرب حين استتد على سماحة الرسالة المحمدية وشمولية

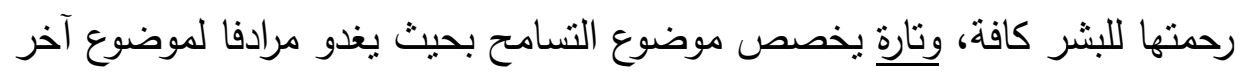

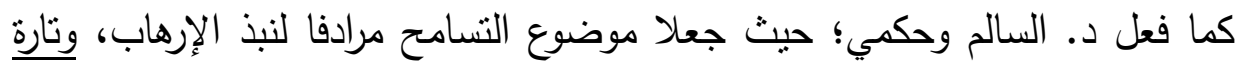

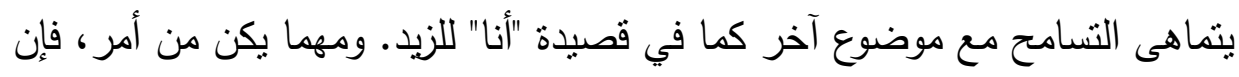

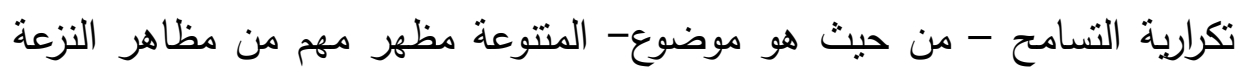
الإنسانية لاى شعراء الددونة.

(1) إلا الوطن- مجموعة شعرية-، إعداد: غرامة خلوفة العمري، النادي الأدبي بمنطقة تبوك، ط

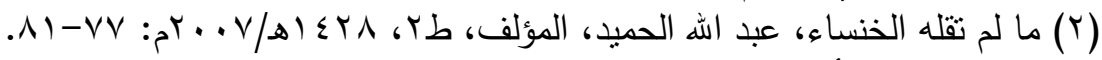

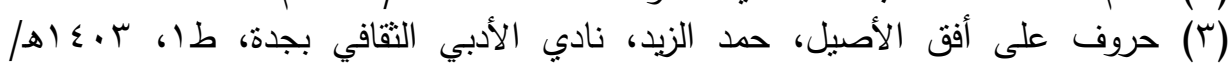




\section{ب د · محمد بن عبد الواحد المسعود \\ المبحث الثاني \\ الإنسانية - المساواة}

أقرت الثريعة الإسلامية مبدأ المساواة في الكرامة الإنسانية، ورسخت العدل بين الإساه البشر مها اختلف الجنس أو المعتقد أو العادات أو النقاليد. وقد جسد الثاعر السعودي نلك النظرة الإسلامية السامية في مدونته الثعرية، فألفيناه يحض على المساواة، وينبذ أنثكال التمبيز العنصري، بل إنه تجاوز ذلك إلى الحديث بلسان حال من اكتوى بلهيب العنصرية، مع أنه لم يذق مرارتها ولله الحمد.

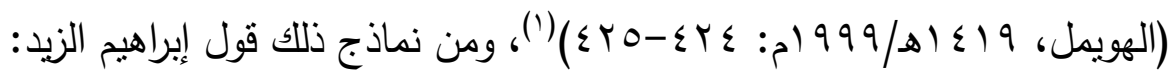

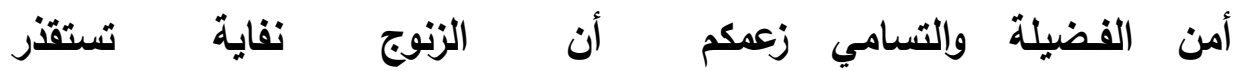

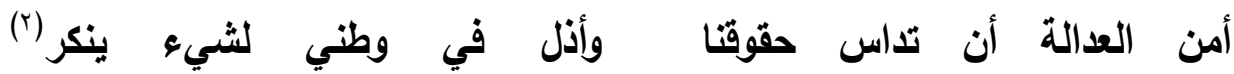
انكأ موضوع المساواة على أسئلة ذات صبغة إنسانية صرفة، فأي مبدأ يجيز

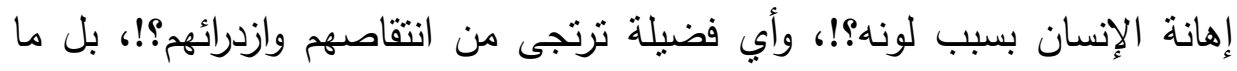
الغاية السامية النبيلة من إهانة من خلقه الله وكرمه على غبره من المخلوقات؟!. قال

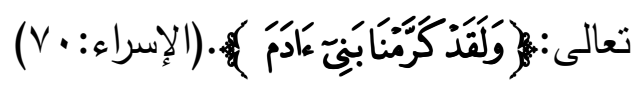

تكثف تراكية تلاك الأسئلة مشاركة الثناعر السعودي غيره من بني البشر همومهم وأحزانهم، ومن ذلك التمييز العنصري الذي ينبذه الدين الإسلامي، وترفضها

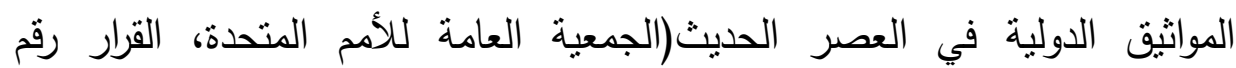
(r).

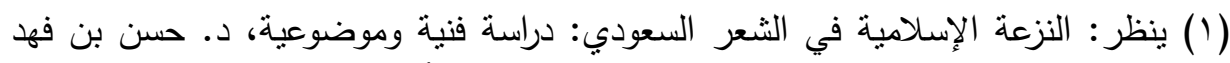

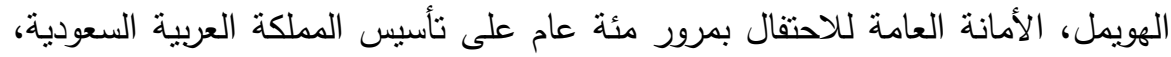
.

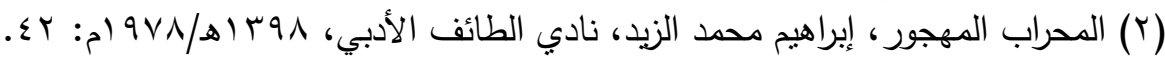

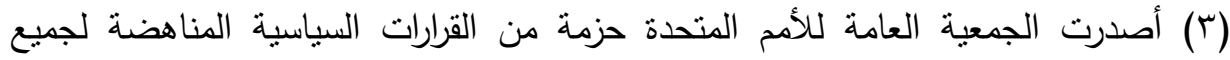

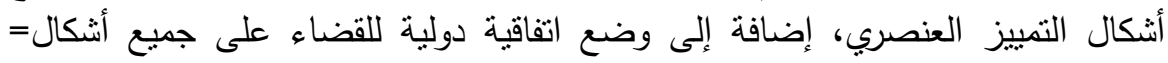


وقد مزج بعض الثعراء موضوع المساواة بموضوعات ذات أبعاد دينية، نؤكد الأبها النزوع الإنساني الإسلامي لاى الثاعر السعودي، ومن نماذج ذللك مزج ضياء الدين رجبيين موضوعي: المساواة، والحج في قوله:

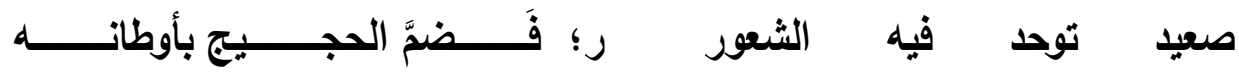

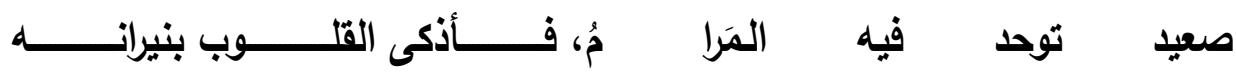

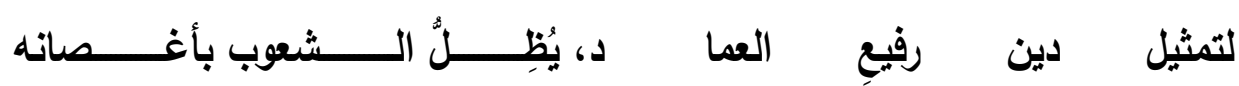

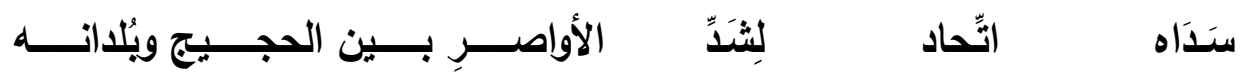

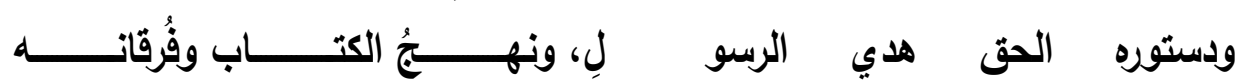

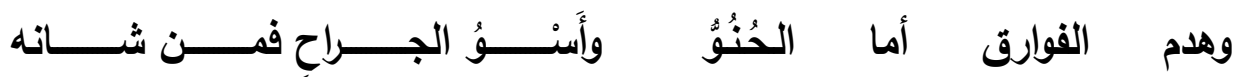

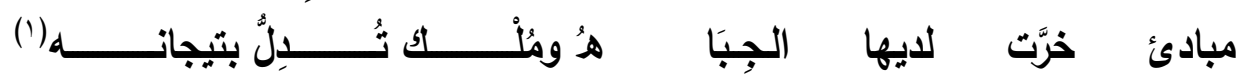
إن المساواة بين البشر مبدأ إسلامي عظيم، بمثله وقوف المسلمين على صعيد واحد، دون تفريق بين عربي وعجمي، أو بين أبيض وأسود. وتلك المساواة تمنت لتشمل

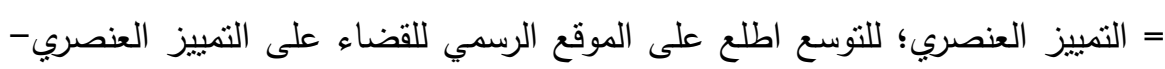

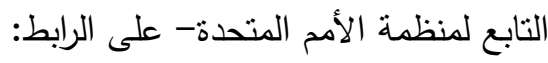
http://www.un.org/ar/events/racialdiscriminationday واطلع على الاتفاقية الدولية للقضاء على جميع أثنال التمييز العنصري، في القرار رقم

$$
\text { (T) }
$$

http://www.un.org/ar/events/torturevictimsday/assets/pdf/rro_PDFl.pdf

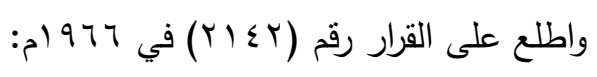

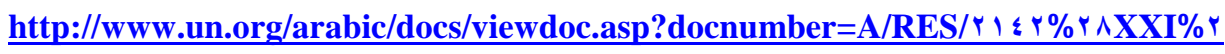

\section{q \& Lang=A}

$$
\text { واطلع على بقية الونائق على الرابط: }
$$

http://www.un.org/ar/events/racialdiscriminationday/documents.shtml

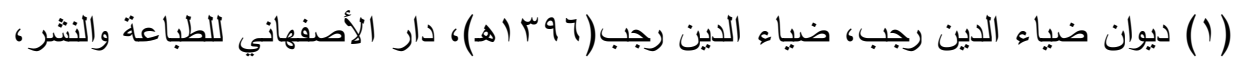

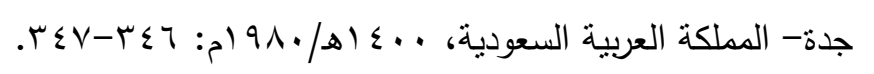$$
-11 \leqslant-
$$ 
בص د · محمد بن عبد الواحد المسعود يـ بقية البشر؛ ذلك أن الدين الإسلامي دين إنساني عظيم يظل جميع الشعوب بسماحته ووسطبنه.

وفي قصيدة:"أم القرى"مزج محمد السنوسي موضوع المساواة بالرسالة المحمدية:

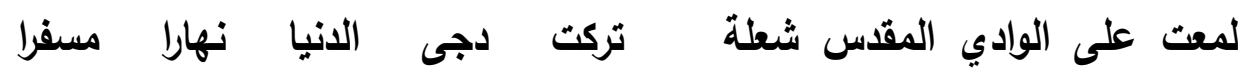

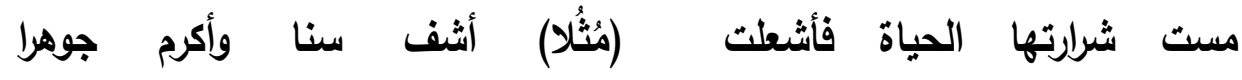

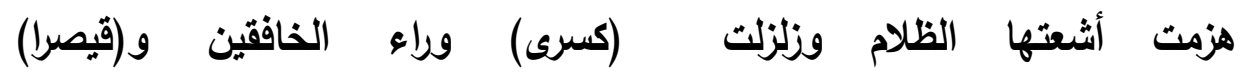

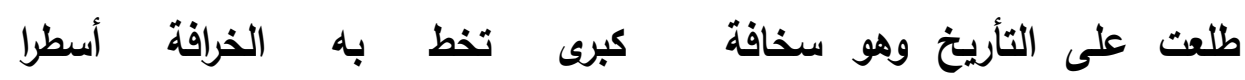

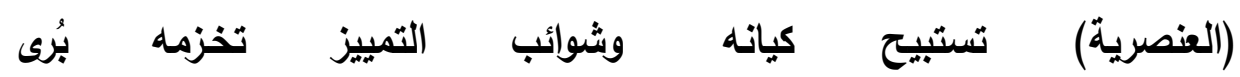

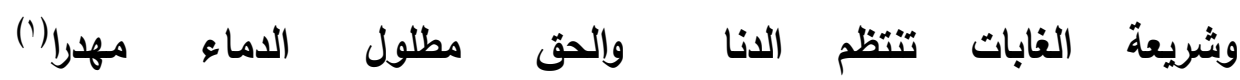
فالرسالة المحمدية نور فطري فتع ظلام العنصرية التي استباحت الشعوب، وسلبت حقوقها، ونشر -في الوقت نفس- العدل والمساواة دون تفريق بين البشر . كما مزج بعض الشعراء موضوع المساواة بموضوعات ذات أبعاد حديثة وتاريخية. ومن نماذج ذللك قصيدة: "فقير يهود" لعبد العزبز الريس؛ التي ضمنها هواع بهاء موضوعات: ا - عدل الإسلام وسماحته وترسيخه للمساواة بين بني البشر • ץ- عدل عمر -رضي الله عنه-، ومساواته بين أفراد المجتمع دون تمييز بينهم

$$
\text { بسبب دين أو لون. }
$$
ب- رحمة عمر -رضي الله عنه-. ــ الفقر في الدولة الصهيوينة في العصر الحديث.( مؤسسة الفكر العربي،

$$
{ }^{(r)}\left(r^{2}+1\right)
$$

(1) الأعمال الشعرية الكاملة، محمد بن علي السنوسي(V •ـ (هـ)، نادي جازان الأدبي، المملكة

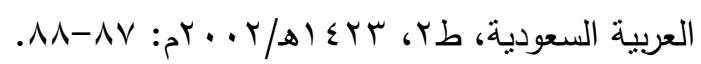

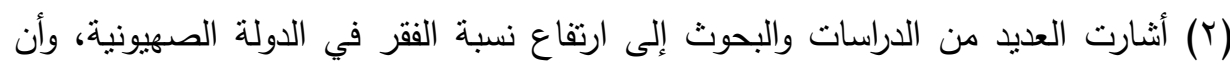
الدولة العبرية لم تعد دولة رفاه، بل دولة فقر وفقراء تزداد نسبهما كلّ عام.فقد أثنارت 
النزعة الإنسانية

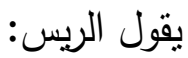

فقير يهوذْ..

ترنّح في طرقات حياه

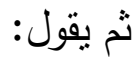

فقير يهوذ

واللامع يُجاوز حنجرة المسكين

والعين تجاور أشتلاءً

ويقايا صورِ مرميْْ

ويقايا الذكرى تمسح عن ذاكرة الحب غبار

سنينْ

فقير يهود

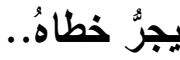

بقيد سنين

وتُقل حياه

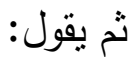

فقير يهود

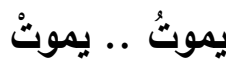

في كل دقيقهُ

مع كل الأنفاس الحرَّى

=مؤستّة التأمين الوطني الإسرائيلي- مثثلا- في تقريرها السنوي إلى ارتفاع عدد المواطنين

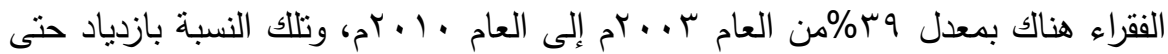

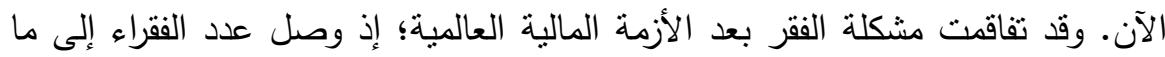

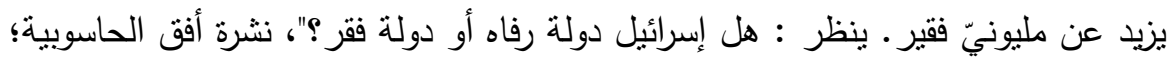

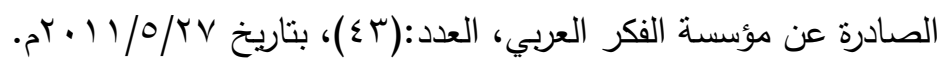




$$
\begin{aligned}
& \text { يموتُ .. يموتْ } \\
& \text { مع كل دقيقة ذكرى } \\
& \text { وينادي: } \\
& \text { أين .. عمز؟. } \\
& \text { أين .. الفاروق؟!(') }
\end{aligned}
$$

يكثنف تراكُم تلك الموضوعات الموضوعَ الأساس في النص، وهو المساواة بين بني البشر في الحقوق والواجبات؛ فاليهودي في القصيدة هائم في الطرقات بحثًا عن

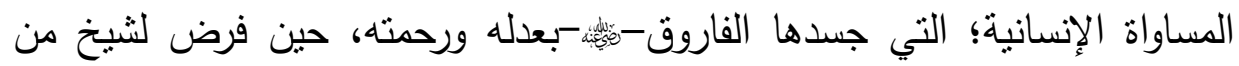

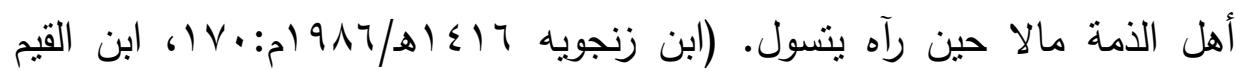

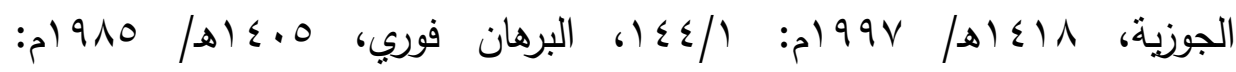

$$
\cdot(r)(\varepsilon 9 \Lambda / \varepsilon
$$

وقد استل بعض الشعراء موضوعات صغرى من موضوع المساواة، كما فعل

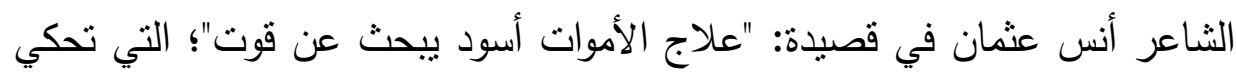
قصة رجل أسود رفض المستشفى استقباله بسبب لونه؛ وأمره بالذهاب إلى مستشفى السود، بيد أنه توفي قبل أن بصل إليه.

(1) رسائل إلى النجوم، عبد العزيز الريس، دار الكنوز الأدبية، بيروت، طا، ب.. بrم: \ه-

(r) ينظر : كتاب الأموال، حمبد بن زنجويه (Y01) (10ه)، تحقيق: د.شاكر ذيب فياض، مركز

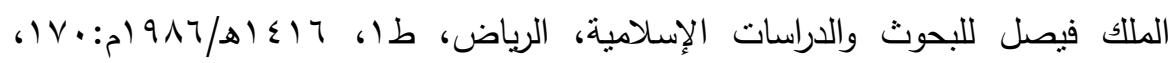

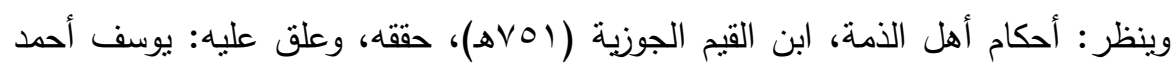

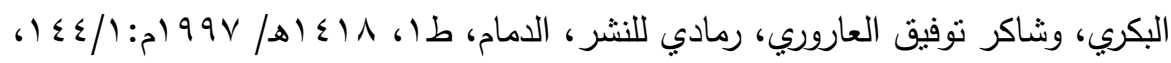

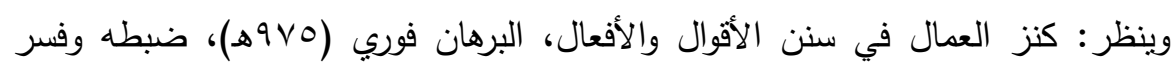
غريبه: بكري حيّاني، صححه، ووضع فهارسه ومفتاحه: صفوة السقا، مؤسسة الرسالة،

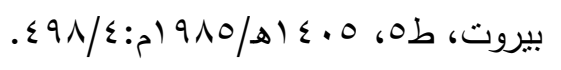


وقد تضنت القصيدة عدة موضوعات ترسخ موضوع المساواة، وأهم تلأك الإسابه

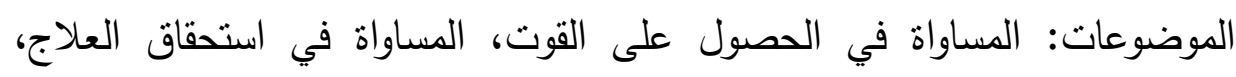

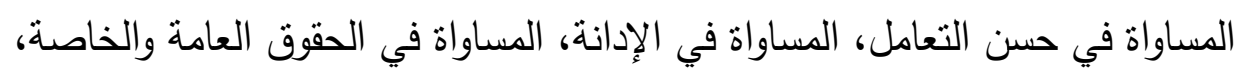

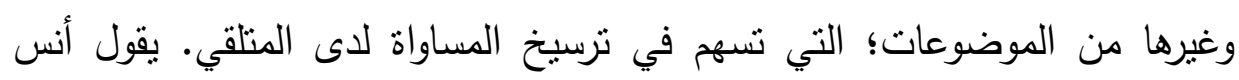
عثمان:

فالناس هنا

في هذى البقعة صنفانْ فئة بالثر تدين

وأخرى بالخير ثُدانْ

لم تعلُ بها أبدا للعدل يدان

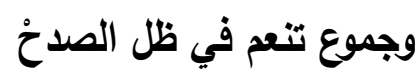

وجموع تثثى في ظلم الكدخ

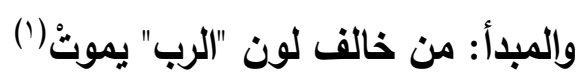

فالفحمة في القيمة غير الياقوتُ فئن

والمبدأْ

ما أملى الأعلى .. مبلى

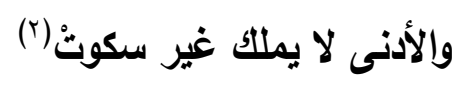

ويقول مصورا هموم الرجل الأسود وأحزانه، ومعاناته من العنصرية: وتميد به الانيا وتدور

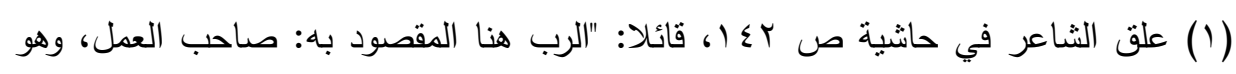

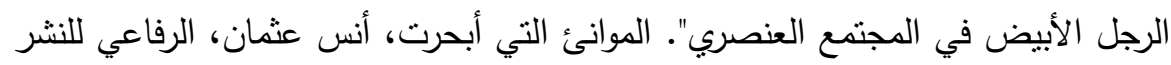

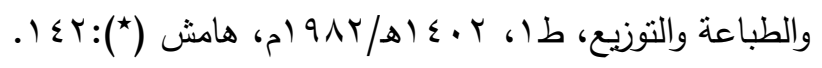

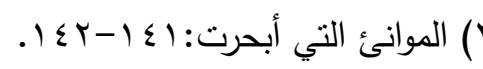




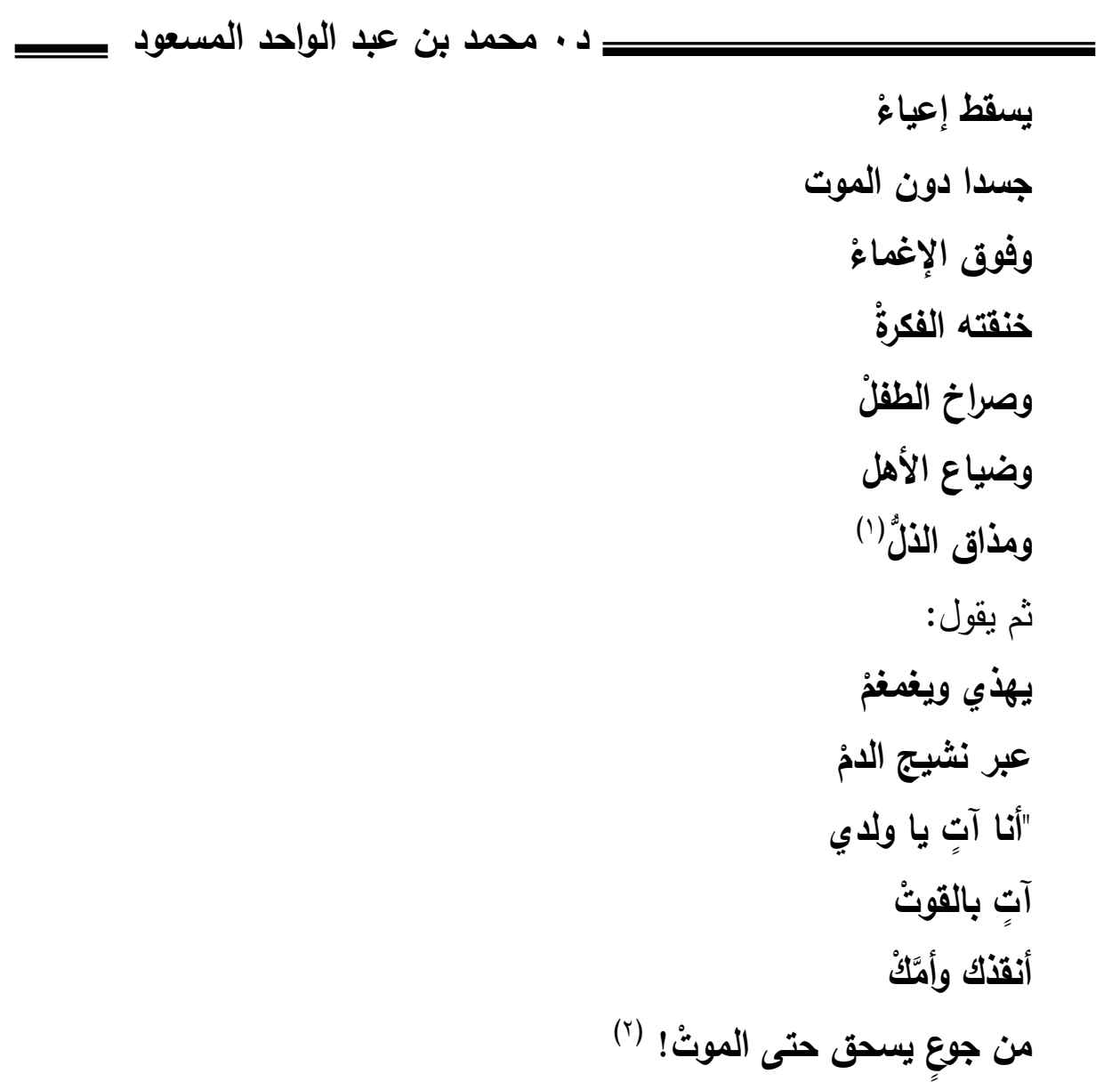

ويندرج تحت موضوع المساواة موضوع المواساة؛ المتمتل في تضامن الثناعر

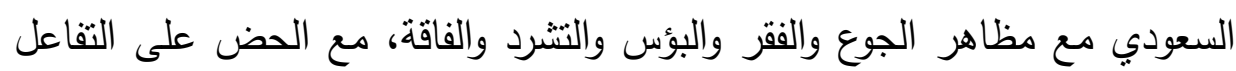

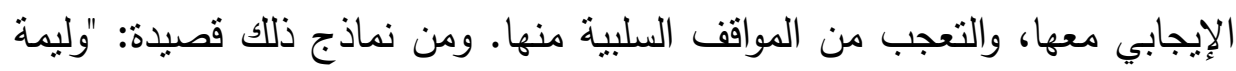

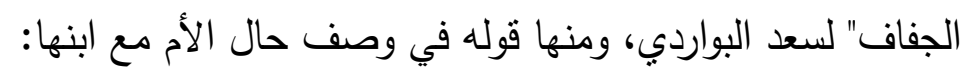

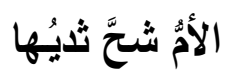

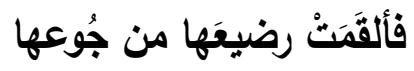

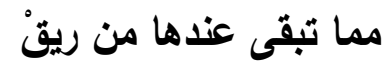

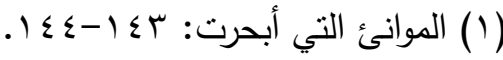

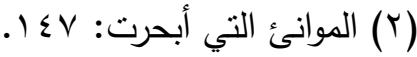


בب النزعة الإنسانية

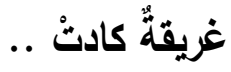

ومَدَّتُ يَََها

لقلذة من كباٍ ..

كان غريقُ ..

وألف ألف جسد مهجور

تطاله الأنابُ والنسور

ثم يقول متعجبا:

أثثكي لمن؟!

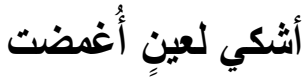

كي لا ترى موتَّ الجياعْ؟!

أثثكي لأنن أطبقتْ

من حولها رعد ارتياع!!(')

(1) قصائد تخاطب الإنسان، سعد البواردي، الصافي للثقافة والنشر، الرياض، طا،

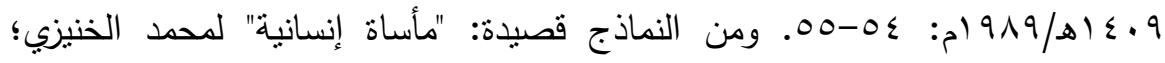

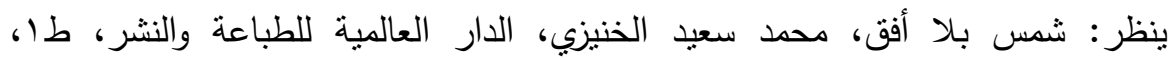

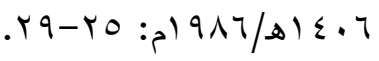

$-1 Y \cdot-$ 
.

\section{المبحث الثالث}

$$
\text { الإنسانية - السلام }
$$

اختص الله سبحانه وتعالى الإنسان من بين مخلوقاته بالكرامة والمنزلة الرفيعة،

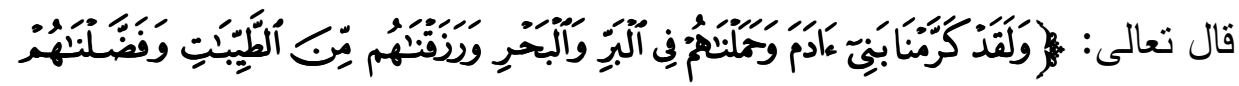

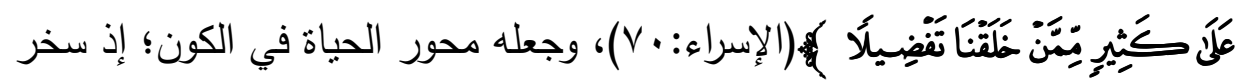

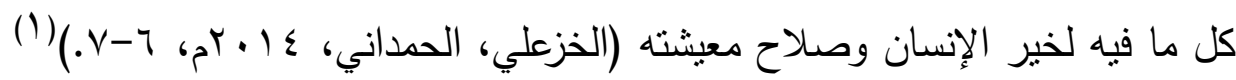

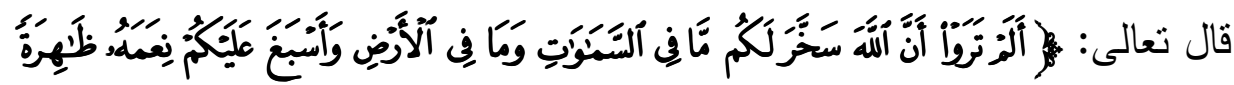

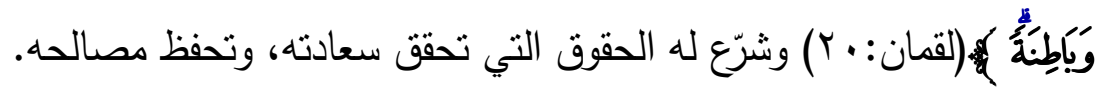
وقد قرر القرآن الكريم تلاك المنزلة، ورسخ تلك الحقوق، في هيئة تتسم بالثمولية

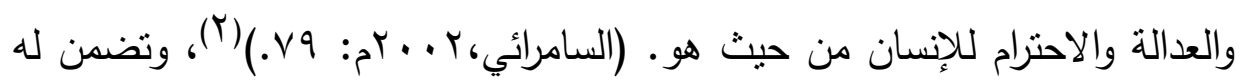
الحياة الكريمة مع التأكيد على تأطيرها بالأمن والسام والطمأنينة، ونبذ الإيذاء والاعتداء بمختلف وجوه الأذى وأشكال العدوان؛ ذلك أن الأصل في التشربع الإسلامي عصمة النفس الإنسانية، وتحريم الاعتداء عليها أو إزهاقها بدون وجه حق.

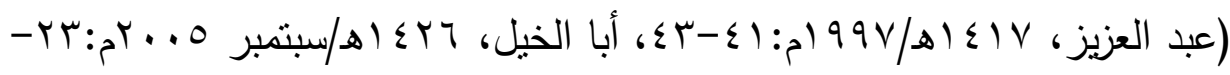

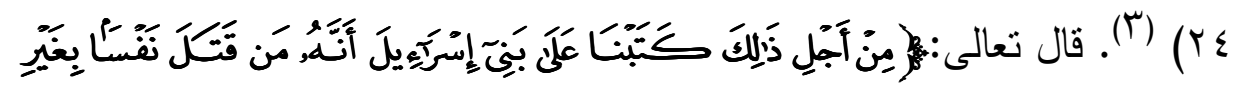
(1) ينظر : مفهوم حقوق الإنسان في الفكر الإسلامي،أ.م.د.أمل هندي كاطع الخز علي، جابر جواد كاظم الحمداني،مجلة مركز بابل للاراسات الإنسانية، بابل-جمهورية العراق،

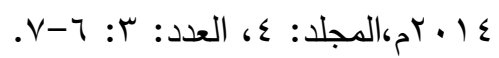

(r) ينظر : مفهوم حقوق الإنسان في الفكر الإسلامي: V، نقلا عن حقوق الإنسان في القرآن الكريم، حقوق الإنسان في الفكر العربي، فاروق السامرائي، مركز دراسات الوحدة العربية،

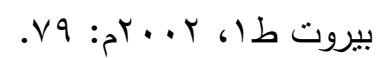

(ץ) ينظر : حقوق الإنسان في الإسلام، د. أمير عبد العزيز، دار السلام للطباعة والنشر

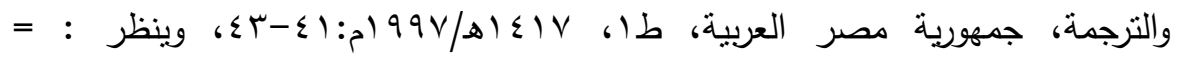




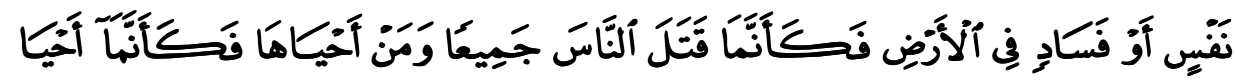

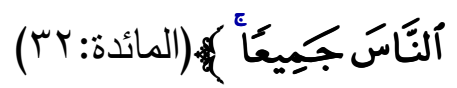

وقد دوَّن الثاعر السعودي -وفق ذلك التصور - جملة من الموضوعات التي

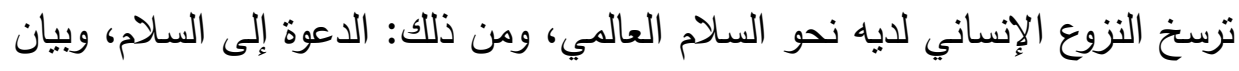

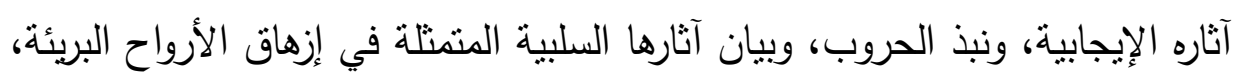

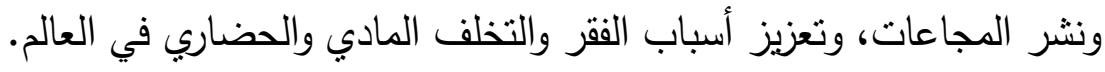

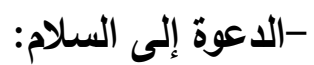

ألح بعض الثعراء على موضوع السلام الإنساني من خلال الدعوة إليه، وبيان

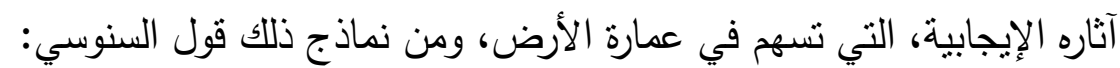

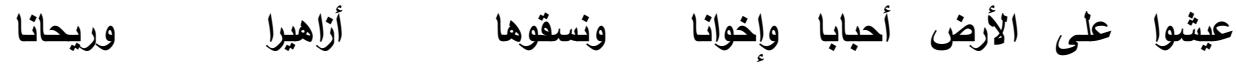

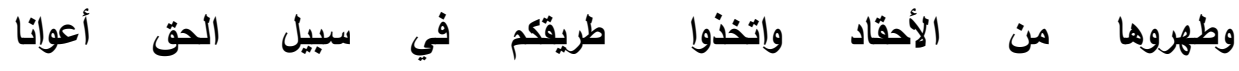

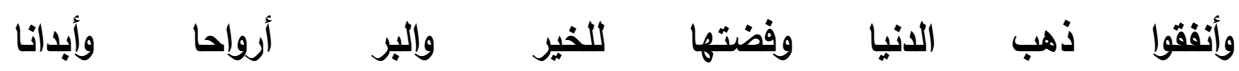
وأنقذوها من(الوحش) الأي ابتليت

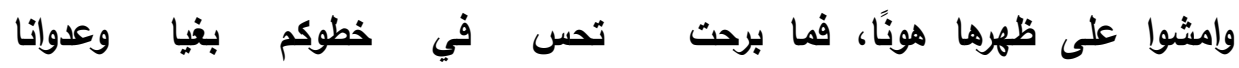

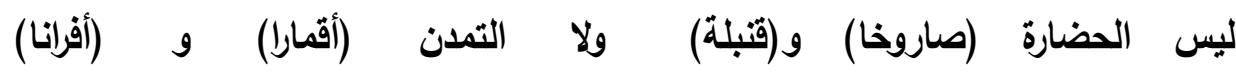

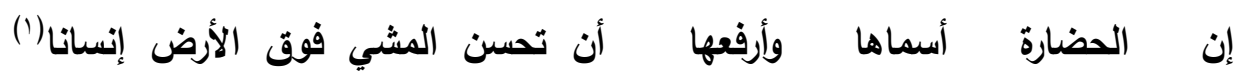
يرتبط بناء الحضارات عبر التاريخ بتكامل عناصر البنية الإنسانية فيها؛

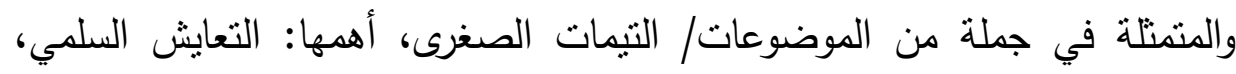
التعارف، التشارك والتفاعل، التواصل التاريخي الحضاري؛ بحيث يكون الحاضر التمان

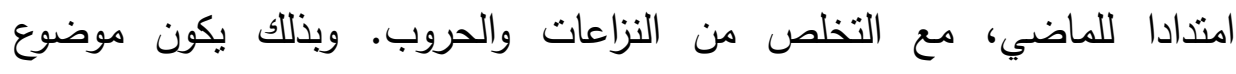

=حماية ضحايا الحروب في الثريعة الإسلامية، أ.د.سليمان ابن عبد اله أبا الخيل، مجلة

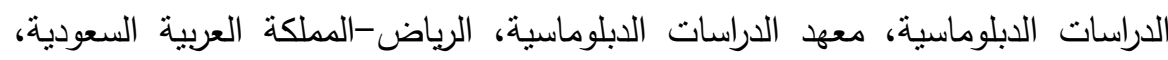

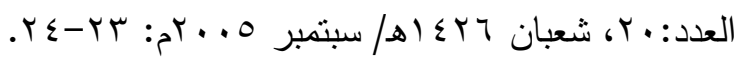

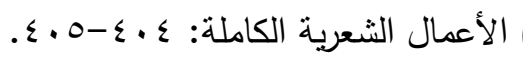




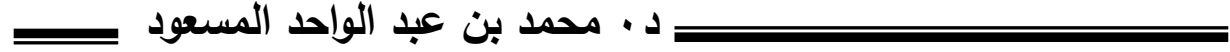
الإنسانية/السلام (الدعوة إلى السلام) قائما على حركية موضوعانية بمكن إجمالها في

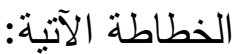

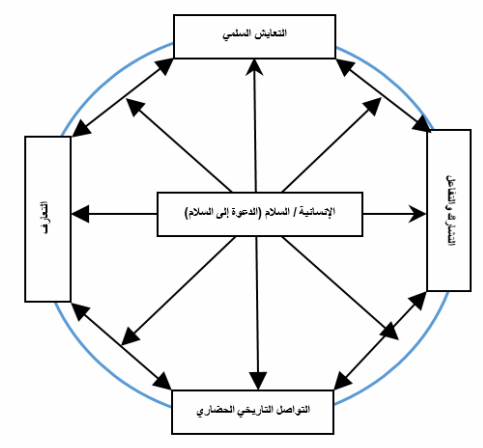

ومن النماذج -أيضا- قصيدة: "عروبة وإسلام" التي دعا فيها طاهر زمخشري إلى السلم مع ترسيخ إنسانية الإسلام، ودعوته للسلام. يقول الزمخشري:

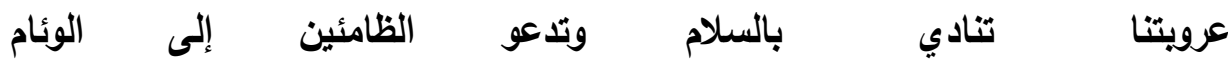

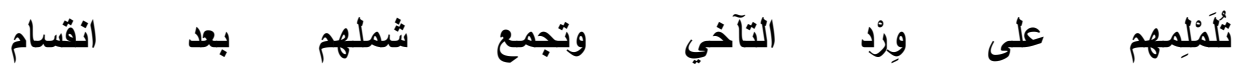

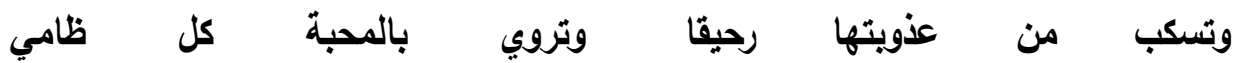

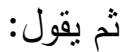

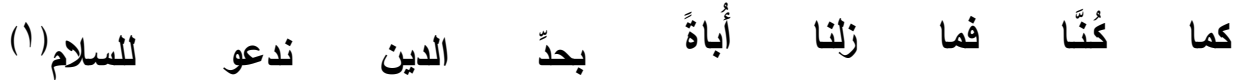
-الموازنة بين موضوعين، هما: أضرار الحروب، وايجابيات السلام: وازن بعض شعراء المدونة بين موضوعين منقابلين، هما: أضرار الحروب، وإيجابيات السلام؛ لوضع المتلقي أمام موازنة عقلية فطرية بين حالتين: الحالة الأولى: موضوع الحرب وآثاره السلبية.

(1) من الخيام، طاهر زمخشري (V•؛(ه)، الثركة التونسية لفنون الرسم، طץ،

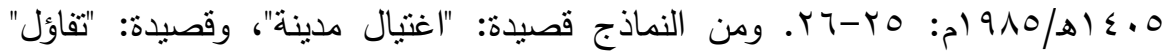
لحسين سهيل؛ ينظر : وللأقمار باب، حسين سهيل، نادي جازان الأدبي 9 اـأهـ| .or ، $\{7-\varepsilon r:$ : 1999 


\section{الحالة الثانية: موضوع السلم وآثاره الإيجابية.}

تقود تلك الموازنة المتلقي إلى الإقرار بأهمية السلم، ودوره في تحقيق الحياة

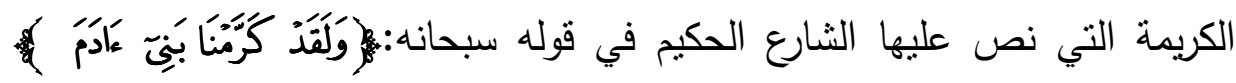
(الإسراء: •V). وبذلك يكون الثاعر السعودي-الزمخشري مثلا - داعيا للسلام ومنفرا من الحرب من خلال الموازنة بينهما.

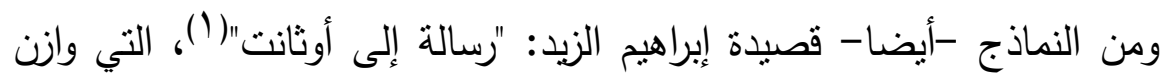

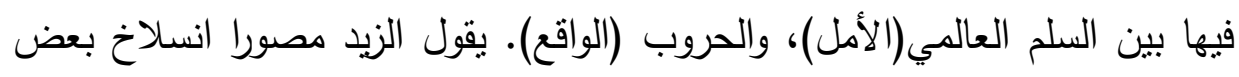

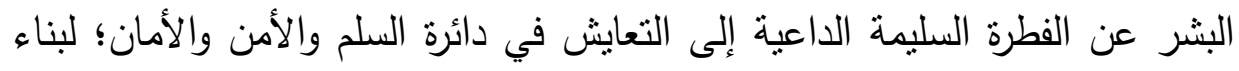

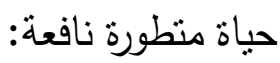
في قرنتا العشرين .. في عصر الفضاء ..

ويلوغنا الأفلاك في هذي السماءو..

وتطلع الإنسان ..

للزهراء .. بعد بلوغه القمر المنير ..

لم يستطع .. برهز

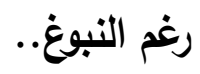

وذهنه الصافي الكبير..

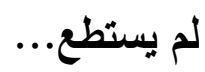

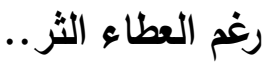

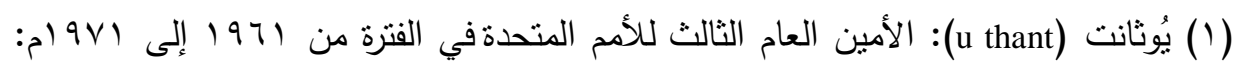
ينظر : ويكييديا -الموسوعة الحرة- عبر الرابط الثبكي:

/يو_ثانت/htps://ar.wikipedia.org/wiki 


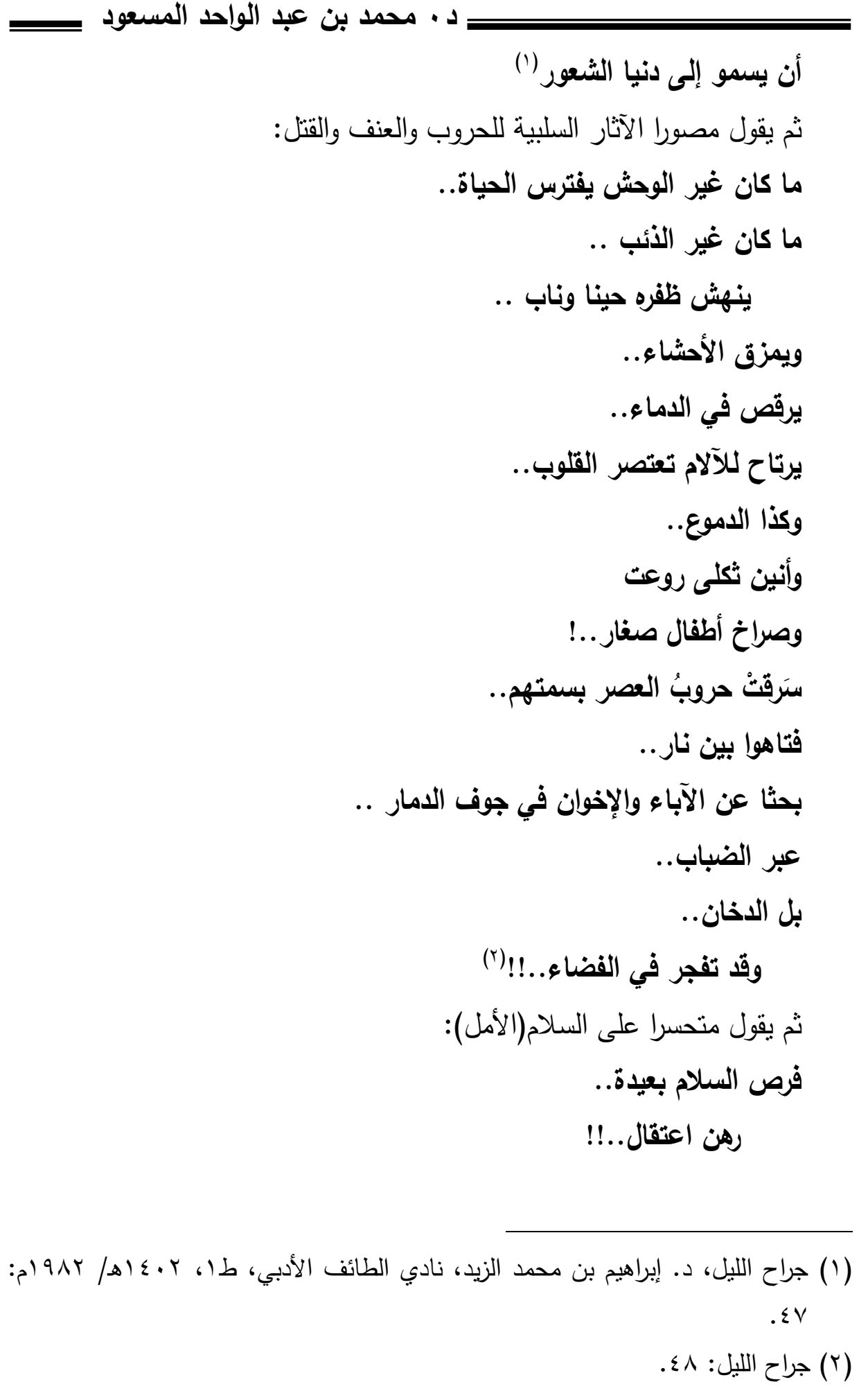


النزعة الإنسانية

ومبادئ الإنسان تفنى..

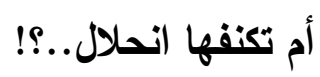

"أو ثانت" عفوا أن أطلت هنا الحوار ..

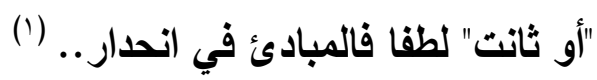

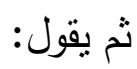

أسفًا على أمل التعايشـ.. أن يرلق ..!

أسفا على ذاك الثراع..

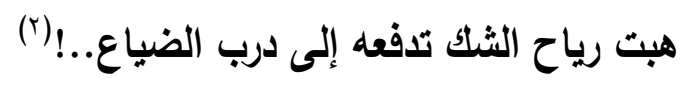

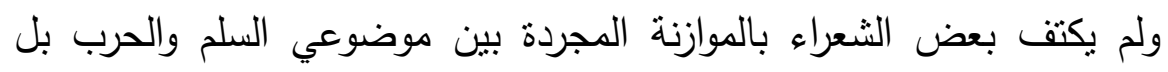

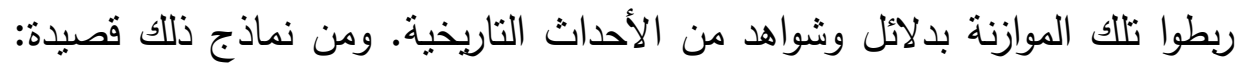

"القنبلة الذرية والإنسان" التي عرض فيها الثاعر صالح العثيمين الآثار السلبية للقنبلة الذرية في (هيروشيما) في نهاية الحرب العالمية الثانية. يقول العثيمين:

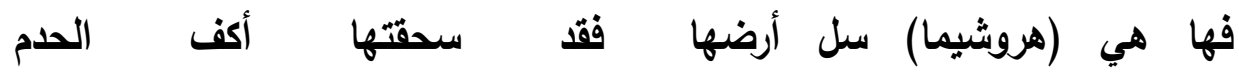

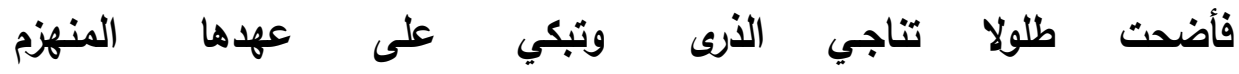

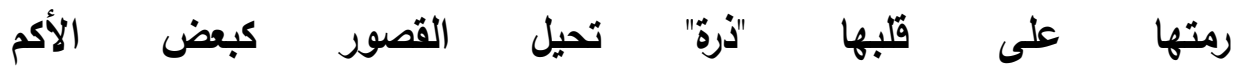
ثم يقول:

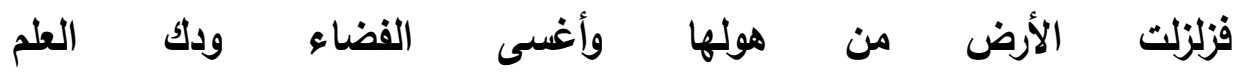

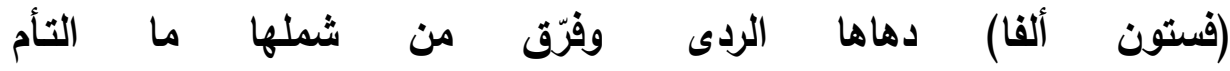

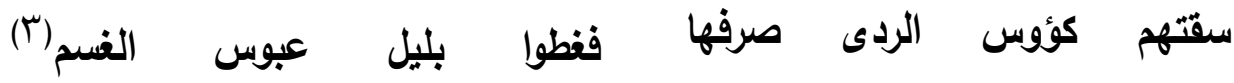
نوازن الأبيات السابقة بين حال (هيروشيما) قبل القنبلة الذرية وبعدها، بل حال

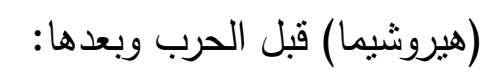

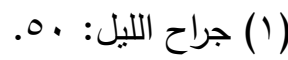

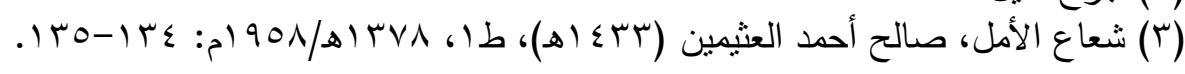




\begin{tabular}{|c|c|}
\hline موضوع الحرب:(هيروشيما بعد & موضوع السلم:(هيروشيما قبل \\
\hline الهوف - القتل - سفلك الدماء البريئة- & الالأمن - الأمان - الحياة الكريمة - الحضاري - الآلت - النور - النطور \\
\hline
\end{tabular}

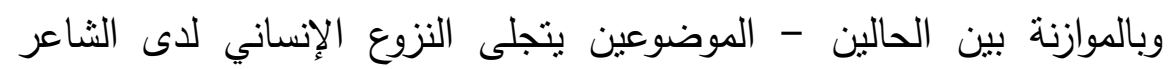
السعودي؛ المتمثل في تكريس الدعوة إلى السلم، ونبذ الحروب بأنثكالها كافة.

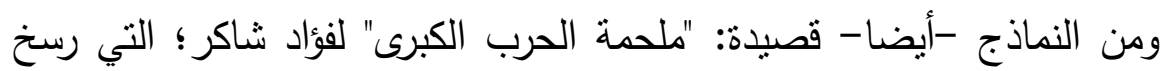

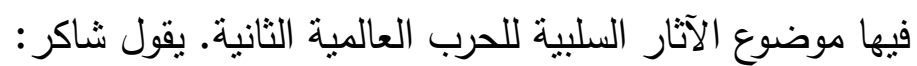

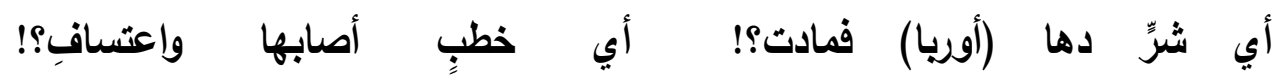

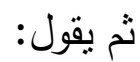

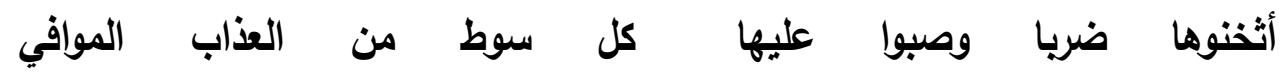

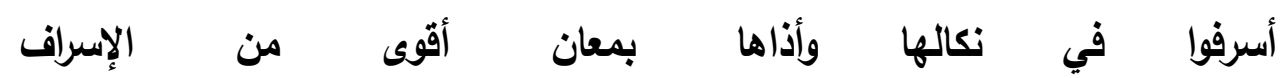

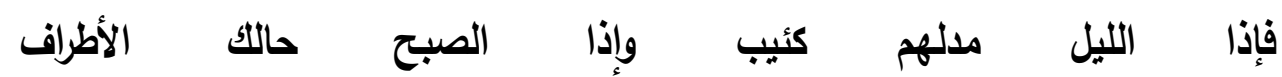

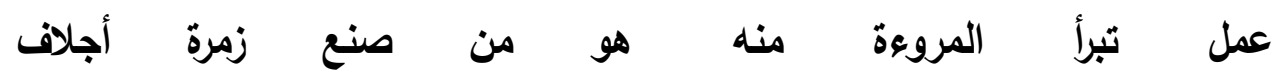

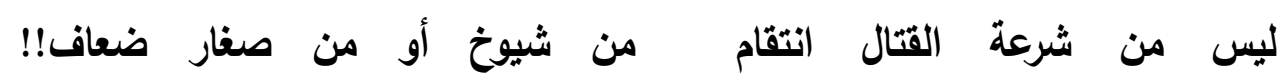

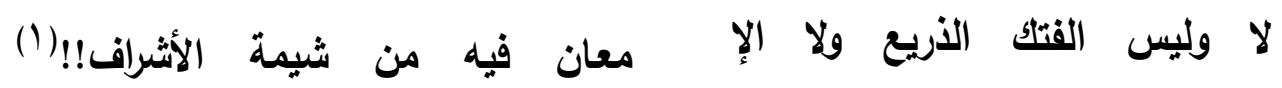

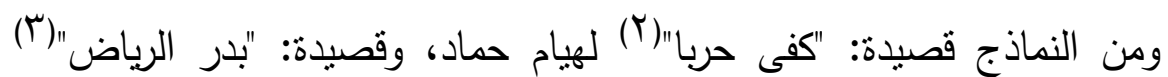

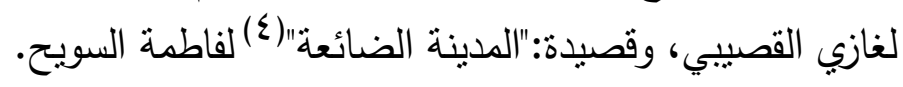

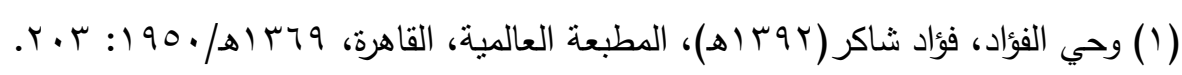

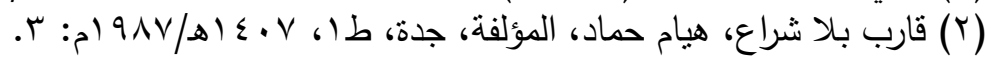

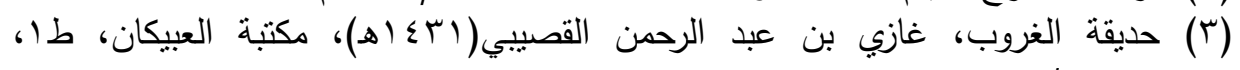

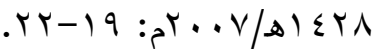

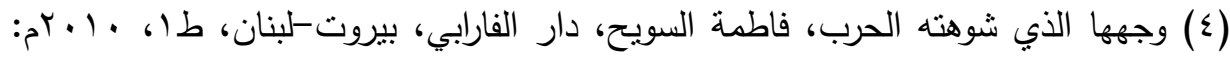

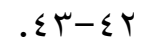




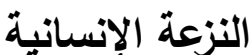

\section{المبحث الرابع}

\section{الإنسانية - التواصل الحضاري}

إن الاختلاف بين الأمم وتمايزها في المتنقدات والثقافات والحضارات، واقع بإرادة الله تعالى، ووفق حكمته البالغة؛ مما يقتضي نعارف البشر وتواصلهم وتعاونهم لتحقيق

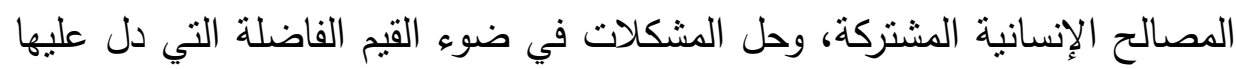
الثنارع الحكيم، بما يسهم في التعايش بين الثعوب بالحسنى، والتنافس في عمارة

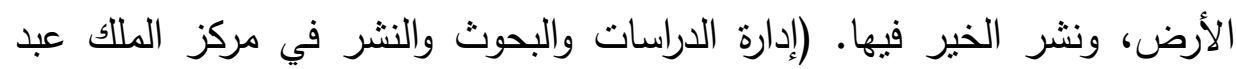

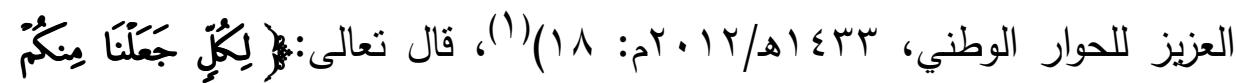

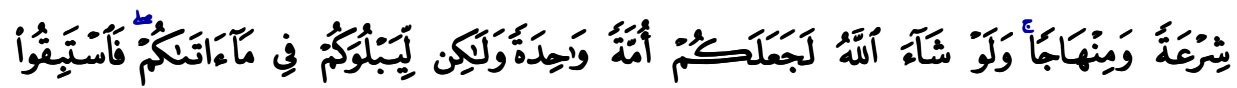

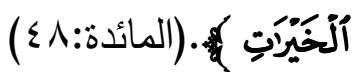

إن التواصل الحضاري بين البشر أمر ضروري؛ فليس في استطاعة إنسان

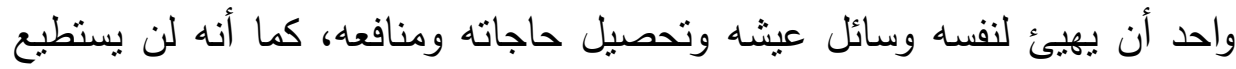

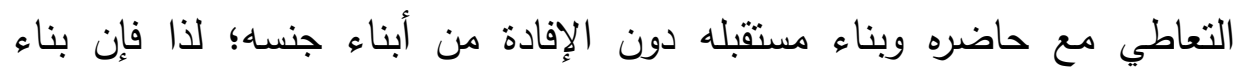
الحضارات ونموها وازدهارها مرنبط بتكريس الطمأنينة بين النفوس البشرية من خلال

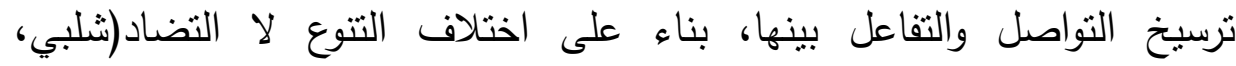

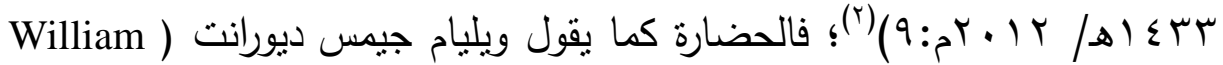
James Durant

( (1) ينظر : مبادرة خادم الحرمين الثريفين الملك عبد الله بن عبد العزيز آل سعود للحوار بين

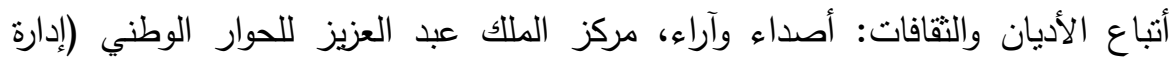

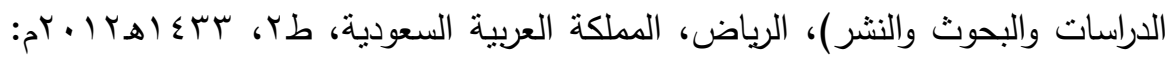

(Y) ينظر : تاريخ الحضارة الإنلامية والفكر الإنسلامي، د.أبو زيد شلبي، مكتبة وهبة، القاهرة،

$$
\text { . }
$$




\section{د د · محمد بن عبد الواحد المسعود}

من الخوف تحررت في نفسه دوافع التطلع، وعوامل الإبداع والإنشاء، وبعدئذ لا تتفك الحوافز الطبيعية تستنهضه للمضي في طريقه إلى فهم الحياة وازدهارها" (وِل

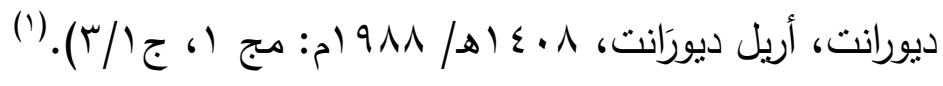
ولم يغفل شعراء المدونة عن موضوع التواصل الحضاري مع الآخر، وأثزه في تعزيز العلاقات الإنسانية، وراح بعضهم يفتق من ذلك الموضوع موضوعات متعددة، منها: أهمية التواصل، وأسسه، وآلياته، وآثاره الإيجابية، وغيرها من الموضوعات لعندات الثيمات الصغرى التي نتراكم لنتكل الموضوع الأساس: التواصل الحضاري. ومن نماذج ذلك قصيدة: "عالم الإنسان" لغازي القصيبي؛ التي دون فيها أهمية التواصل الحضاري وأسسه. يقول القصيبي:

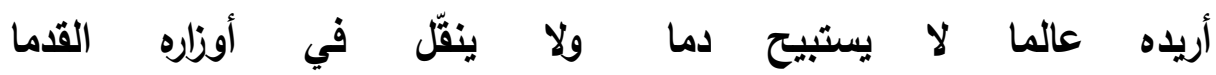

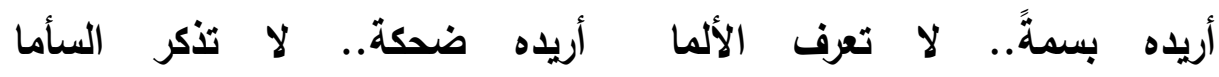
أريده دون خوفٍ .. دون عاصفة سوداء تنثر ليل الرعب .. والعدما

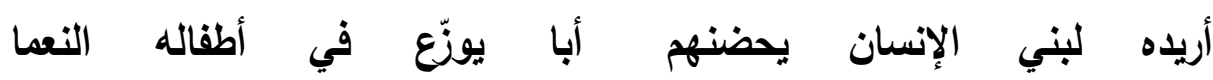

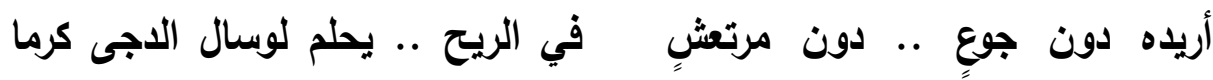

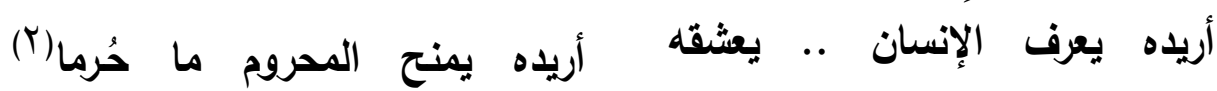
تستحث التجربة السابقة الإنسان على تلمس أسس الإنسانية المثالية مع الالنزام بها. وأهم تلأك الأسس التواصل الحضاري القائم على جملة من الموضوعات، أهمها:

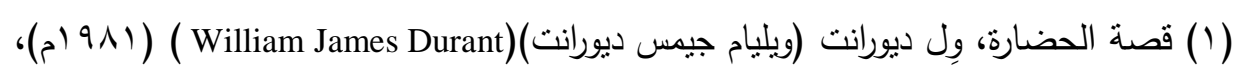

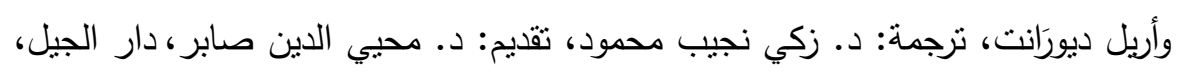

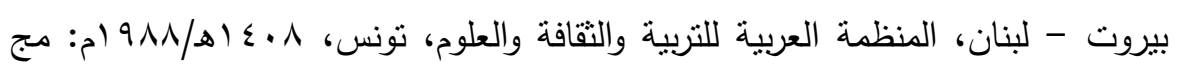

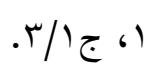

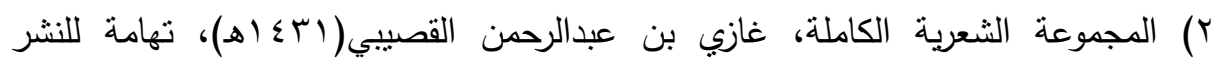

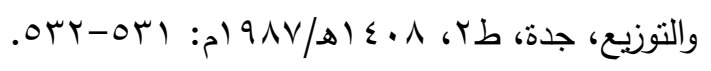




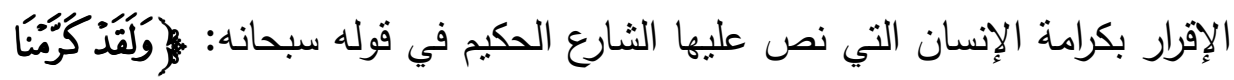

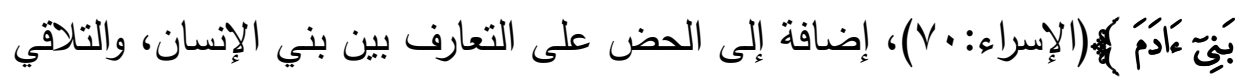

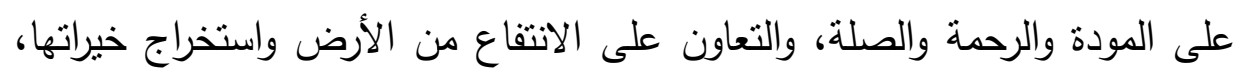
والسعي إلى نشر الخير والحق فيها بما بحقق الإنسانية في صورتها المثالية.

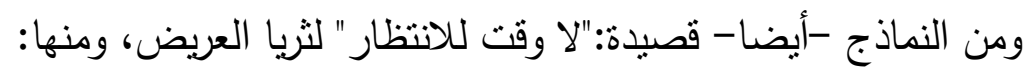

$$
\begin{aligned}
& \text { أتسمعُني في غياهب حبنِكِ. } \\
& \text { تلفُّ وحيدًا متاهاتِ أمسكِك؟ في } \\
& \text { أتثت لأكسرَ أغلالَ يأسيك } \\
& \text { وأعطيَّ وعدَ الحياة } \\
& \text { لا وقتَّ للانتظار .. } \\
& \text { هذي هدايايَ } \\
& \text { كنزُ الطفولةِّة .. قلبي وحبّي } \\
& \text { وأغنيةٌ لانبلاجِ النهار } \\
& \text { أتيتك دون قناع } \\
& \text { أتعرفني أنت؟ } \\
& \text { ثم تقول: } \\
& \text { تعلَّق بصوتي }
\end{aligned}
$$

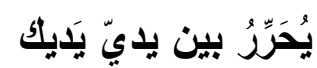

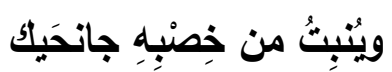

يادعوكَ للطيران..

يدعوك للطيران.. 
د · محمد بن عبد الواحد المسعود يـ

(')... باعوك للطيران

تدعو العريض إلى التواصل الإنساني، ونبذ الانكفاء على الذات، والانقطاع عن

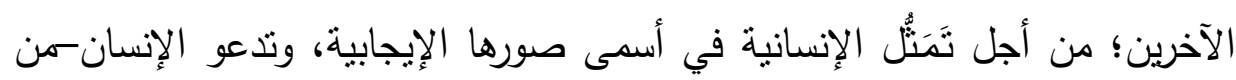
حيث هو - إلى الطيران والتحليق في سماء الآخر، وعدم الركون إلى الانعزال، وتجنب الاكثفاء بالذات؛ ذلك أن الحياة الإنسانية - كما أسلفت من قبل - قائمة على مبدأ

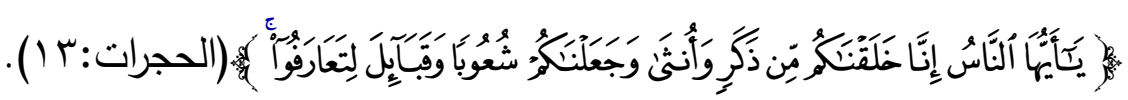
ومن النماذج قصبدة:"أخي أيها الإنسان" لمحمد هاشم رثيد؛ التي دعا في الإنسان -عامة- إلى التعايش والتواصل الحضاري. يقول رشيد:

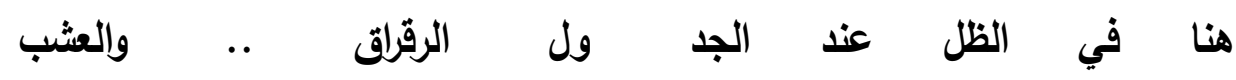

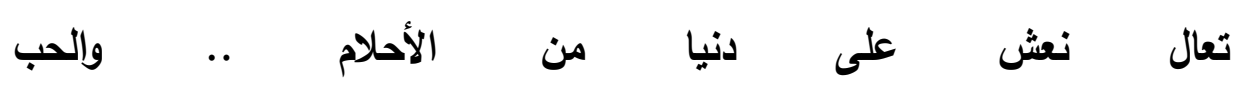

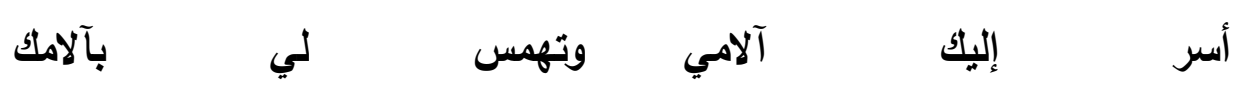
وأنغامك

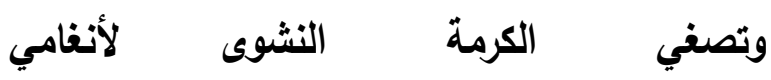
ثم يقول: - م

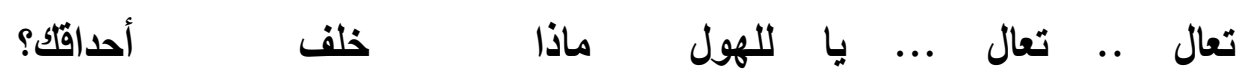

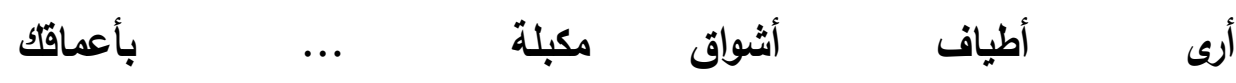

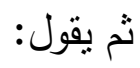

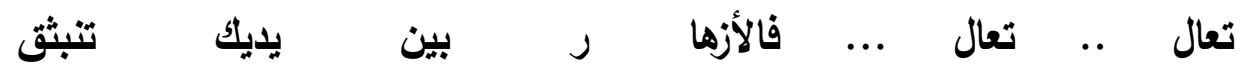

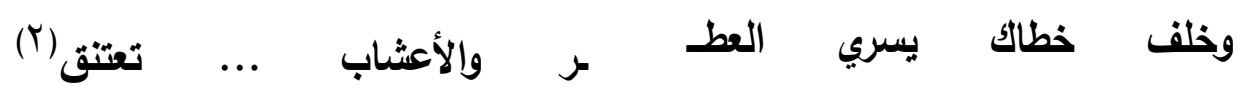

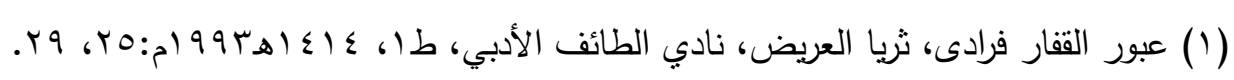

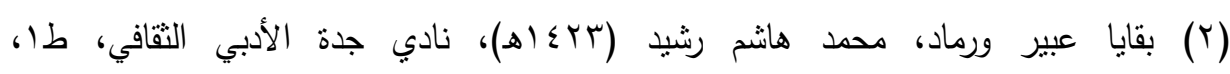
$.07-00$ ، $04-01:$ : $19 \Lambda \varepsilon / 81 \varepsilon$ 
ومن النماذج -أيضا- قصيدة : "غرور الإنسان"((1) الأحمد الغزاوي، وقصيدة :

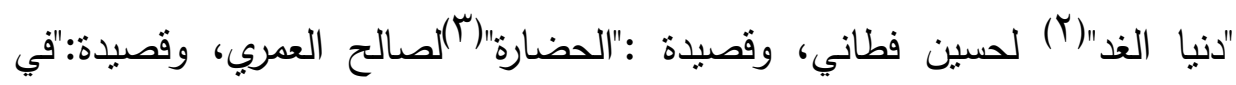

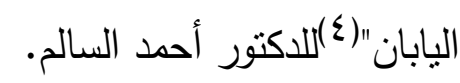

(1) أحمد الغزاوي وآثاره الأدبية، دمسعد عيد العطوي (جمع وتصنيف وتحقيق وشرح)، المؤلف،

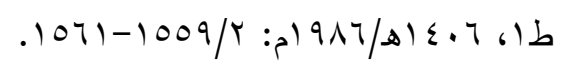

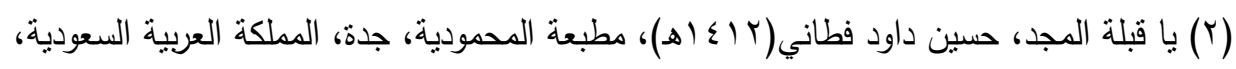

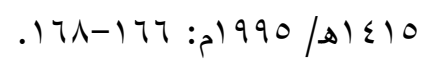

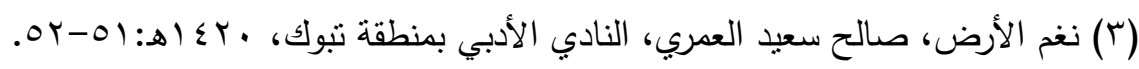

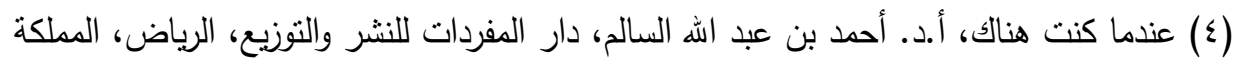

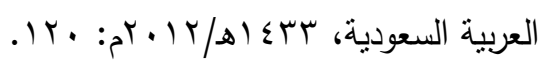
-ITY- 


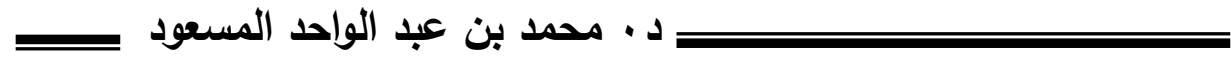

الخاتمة

وبعدُ، فقد ثنَّ البحث بعد مقاربة موضوعانية لموضوعات النزعة الإنسانية في

الثعر السعودي المعاصر، مع تجلية لموضوعاتها الفرعية التي خرجت إليها، وامتداداتها، وتحولاتها، وشبكة العلاقات الموضوعاتية التي انتظمتها؛ لكثف وعي الثاعر السعودي بالإنسانية، وموققه من الإنسان عامة، وما يحمله ذلك الموقف من قيم التسامح والعدل والمساواة والسلام والدعوة إلى الحوار والتواصل، مع نبذ التشدد والغلو والتطرف والعنف والإرهاب. وقد وقف الباحث من خلال على جملة من النتائجة، هي: ا - ترعى المملكة العربية السعودية (حكومة وشعبا) السلم، وتدعو للتسامح والوسطية والاعتدال، وتؤكد التعامل الإنساني مع الحضارات والثقافات المتنوعة، وتحارب العنف والإرهاب بأشكاله كافة. r-لم تخل مدونة البحث من تجليات النزعة الإنسانية عند الثاعر السعودي، مع الإقرار بوجود نباين بين نصوص المدونة في الموضوعات الصغرى، والتشكيلات الفنية. "ا الثعر صورة تعكس قيم المجتمعات ومبادئها، وذلك ظاهر في نصوص المدونة؛ التي كثفت عن اتسام المجتمع السعودي بالإنسانية المستمدة من كتاب الله تعالى وسنة نبيه -صلى الله عليه وسلم-. ع كثنت المدونة عن تفاعل الثاعر السعودي مع الأحداث في العالم، وبخاصة ما يتعلق بالجانب الإنساني، ومن ذلك نبذه للحروب وبيان آثارها السلبية. ๑-رسخ الثاعر السعودي نزعته الإنسانية بالإفادة من نصوص الثرع الحنيف، إضافة إلى الأحداث التاريخية والمعاصرة. 
7- كثف البحث عن أسماء شعرية سعودية ملأت الساحة الثعرية السعودية والعربية بمدونات شعرية؛ لا تقل أهية -من حيث النزعة الإنسانية- عن مثنلاتها في

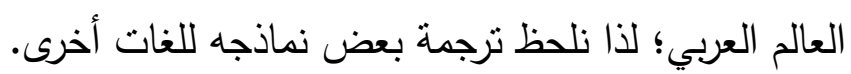

V- استتدت بعض نماذج المدونة على النقابل العقلي بين موضوعين : إيجابي يمثل

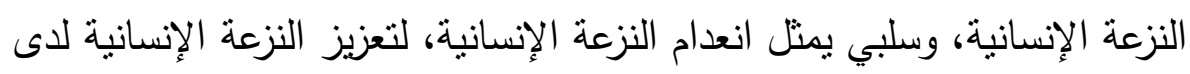

وقد خَلُصت الدراسة إلى بعض التوصيات العلمية، هي:

1- حث الأقسام العلمية والباحثين وطلاب الدراسات العليا على البحث عن تجليات

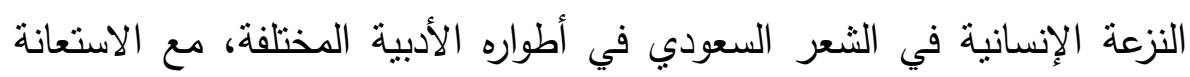
بالمناهج النقدية الحديثة.

r-ترجمة نماذج من الثعر السعودي، وبخاصة النماذج الني تجلي النزعة الإنسانية لاى الثاعر السعودي؛ ليقف العالم على سمة مهمة من سمات المجتمع السعودي. r-تضمنت بعض مصادر المدونة دواوين أو مجموعات شعرية تظلب على موضوعاتها النزعة الإنسانية، ما يجطاها بحاجة إلى دراسات مستقلة.

ع - يحتاج مفهوم الإنسانية الإسلامية إلى مزيد من البحث والتحليل والبرهنة لهخاطبة الآخر وبيان الصورة الحقيقة للإسلام، مع ربط ذلك بالوقائع التاريخية والمعاصرة.

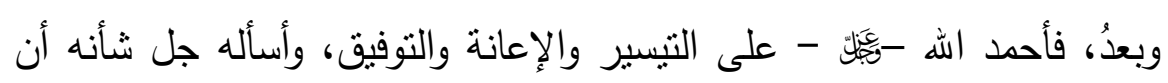
يجعل ما قدمته خالصاً لوجهه الكريم، وأن ينفع به العباد، إنه سميع مجيب. وأثنير إلى النجرد من ادعاء الكمال، فما قُلّم جها بشري يعتريه النقص والخطأ

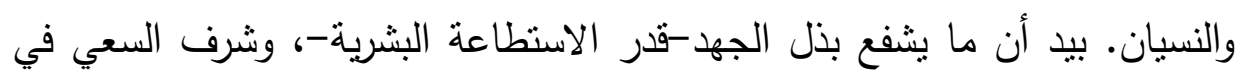




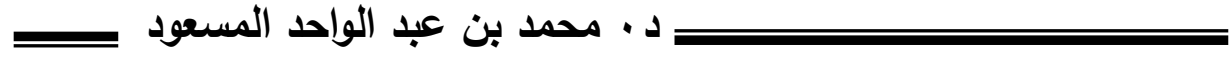
تتبع مواطن الإجادة؛ للوصول إلى تدوين بحث علمي، يعينني مستقبلا عن مواصلة البحث، والتتقيب في العديد من المسائل العلمية. وصلى الله وسلم على نبينا محمد وعلى آله وصحبه أجمعين. وآخر الاعاء أن الحمد لله رب العالمين، كـ 


\section{النزعة الإنسانية}

ثبت المصادر والمراجع

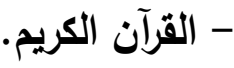

أولا: المصادر:

ا - إجهاشة النبض، حمد بن محمد علا الله حكمي، نادي جازان الأدبي، طا،

$$
\text { . }
$$

r- أحمد الغزاوي وآثاره الأدبية، د.مسعد عيد العطوي (جمع وتصنيف وتحقيق

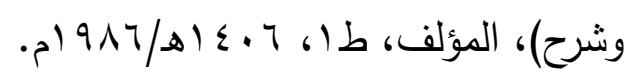

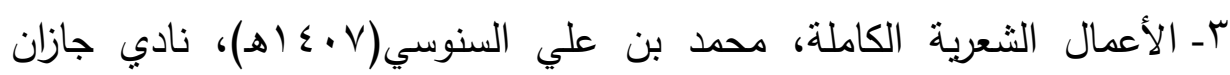

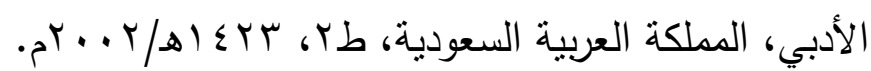

ــ إلا الوطن- مجموعة شعرية-، إعداد: غرامة خلوفة العمري، النادي الأدبي

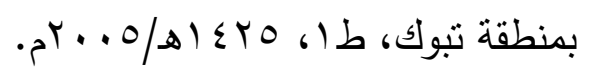

هـ باتجاه الثمس، أبو الفرج عبد الرحيم عسيلان، نادي المدينة المنورة الأدبي،

$$
\text { ط) }
$$

7- بقايا عبير ورماد، محمد هاشم رشيد(ب \& (هـ)، نادي جدة الأدبي الثقافي، طا،

$$
\text { . } 919 \leq / \Delta) \leq \cdot \varepsilon
$$

V- جراح الليل، د. إبراهيم بن محمد الزيد، نادي الطائف الأدبي، طا،

$$
\text { . } 914 / \Delta \mid \leq \cdot r
$$

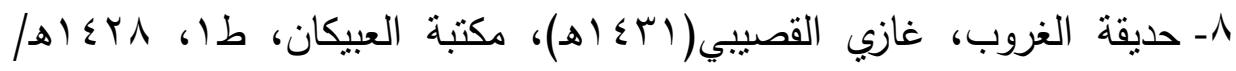

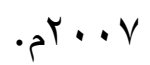

9 - حروف على أفق الأصيل،حمد الزبد، النادي الأدبي التقافي بجدة، ا،

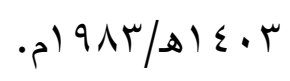

• ا - ديوان ضياء الدين رجب، ضياء الدين رجب(ج9 آهـ)، دار الأصفهاني

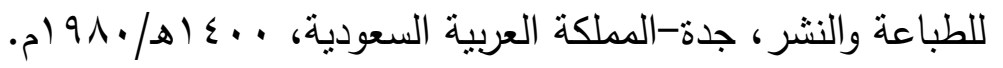




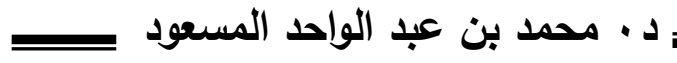

| (- رسائل إلى النجوم، عبد العزيز الريس، دار الكنوز الأدبية، بيروت، طا،

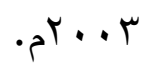

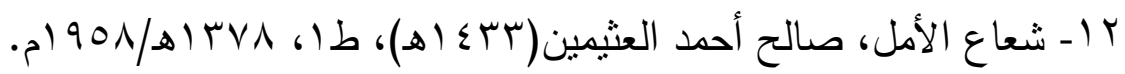

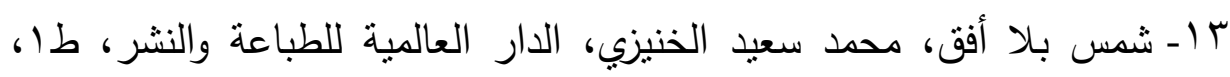

$$
\text { . } 9197 / 81 \leq \cdot 7
$$

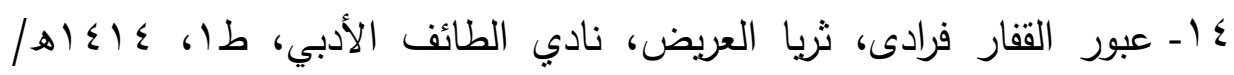

$$
\text { . م) } 99 \text {. }
$$

1 ـ عزف القوافي، عائض مستور الثبيتي، النادي الأدبي التقافي في الطائف، طا،

$$
\text { . } 9 \text {. } 9 \text { / }
$$

7 ا ـ عندما كنت هناك، أ.د. أحمد بن عبد الله السالم، دار المفردات للنشر والتتزيع، الرياض، المملكة العربية السعودية، سبع اهـ/ T ا • بم.

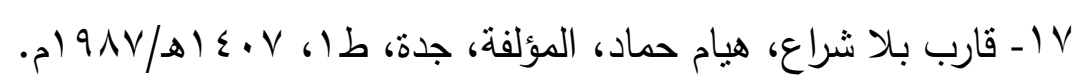

1 ا ـ قبلات على الرمل والحجر، د. أحمد بن عبد اله السالم، هبة النيل العربية

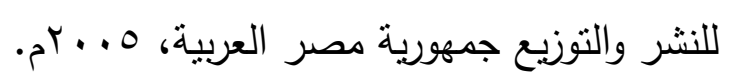

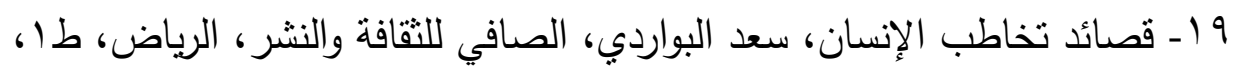

$$
\text { . म) } 9 \wedge 9 / 81 \leq \cdot 9
$$

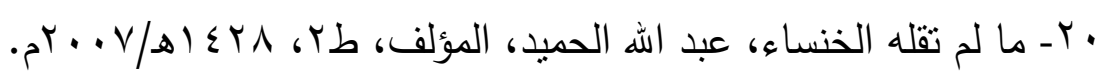
ا آ المجموعة الشعرية الكاملة، غازي بن عبد الرحمن القصيبي(اساء (ه))، تهامة

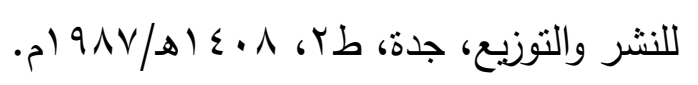

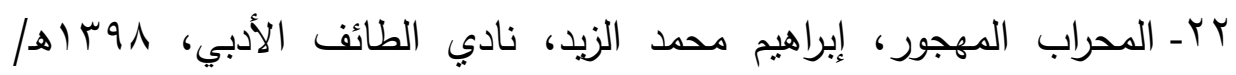

$$
\text { . ) } 9 \vee \wedge
$$

بr- مكتي قبلتي- شعر وشعراء-، إعداد أحمد قنديل(9 9 اهـ)، دار الرفاعي،

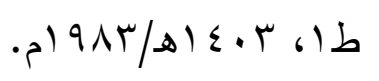




\section{=}

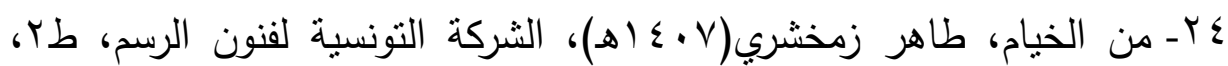

$$
\text { . } 9100 / 81 \leq 0
$$

0 ا - الموانئ التي أبحرت، أنس عثمان، الرفاعي للنشر والطباعة والتوزبع، طا،

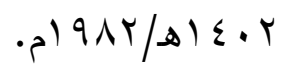

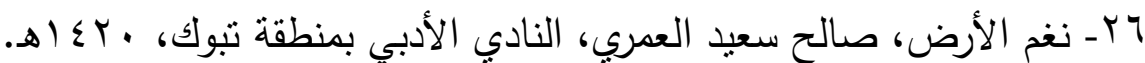

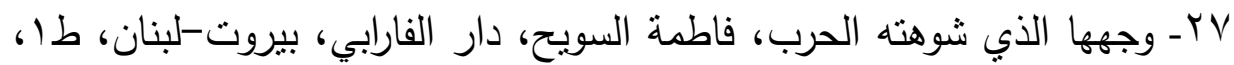
.$Y \cdot 1$.

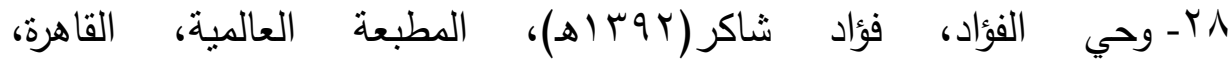
$.190 . / 81179$

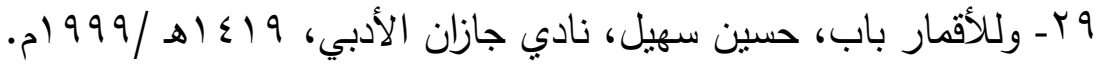

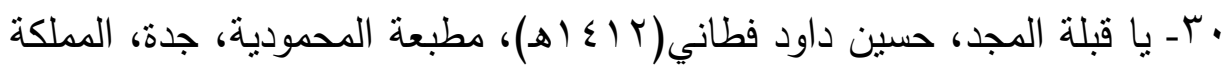

$$
\begin{aligned}
& \text { العربية السعودية، } 0 \text { إـ اهـ/ } 990 \text { (م. } \\
& \text { ثانيا: المراجع: - مان } \\
& \text { أ- الكتب: }
\end{aligned}
$$

1 ـ أحكام أهل الذمة، ابن القيم الجوزية( (10)،ه حققه، وعلق عليه: يوسف أحمد

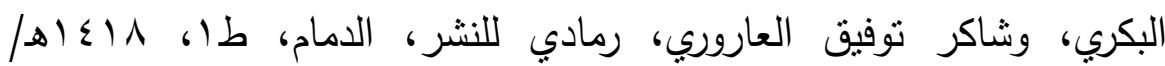

$$
\text { . } 199 \mathrm{~V}
$$

r- الإسلام والحضارة الإنسانية، عباس محمد العقاد(rیr(هـ)، مؤسسة هنداوي

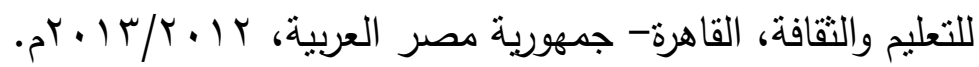

r- إنسانية الإسلام، مارسيل بوازار، ترجمة: د. عفيف دمشقية، دار الآداب بيروت،

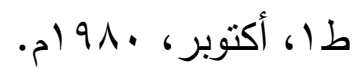

ع - تاريخ الحضارة الإسلامية والفكر الإسلامي، د. أبو زيد شلبي، مكتبة وهبة،

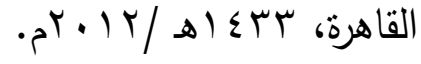




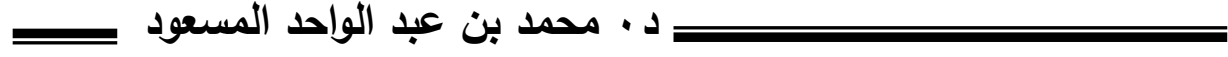

هـ التحرير والتتوير (تحرير المعنى السديد وتتوير العقل الجديد من تفسير الكتاب المجيد)، محمد الطاهر ابن عاشور (بوسا(ه)، الدار التونسية للنشر، نونس،

$$
\text { - }) 9 \Lambda \varepsilon
$$

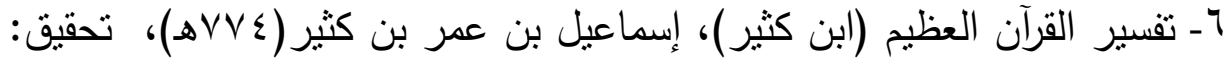

محمد حسين شمس الدين، دار الكتب العلمية، منشورات محمد علي بيضون -

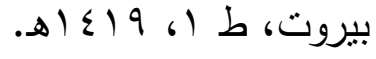

V- جامع البيان في تأويل القرآن، محمد بن جرير الطبري(· •اسه)، تحقيق: أحمد

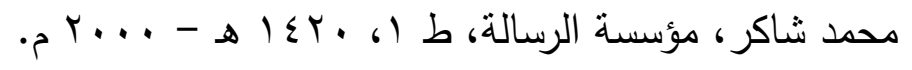

ᄉ- حقوق الإنسان في الإسلام، د. أمبر عبد العزيز، دار السلام للطباعة والنشر

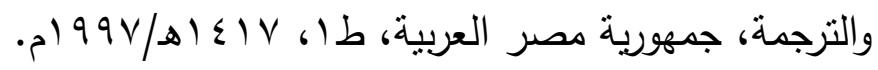

9 - روح الإسلام: تاريخ نطور الإسلام ومتله العليا مع سيرة للنبي، سيد عامر علي،

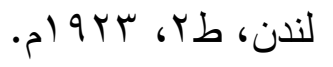

• ا - علم الاجنماع، عبد الرحمن النحلاوي، د.عبد الكريم عثمان، د.محمد خير عرقسوسي، الرئاسة العامة للكليات والمعاهد العلمية، المملكة العربية السعودية،

$$
\text { . م) } 9 \mathrm{~V} \cdot \mathrm{P} \text {. }
$$

| (اـ قصة الحضارة، قصة الحضارة، وِل ديورانت (ويليام جيمس ديورانت) (William James Durant) نجيب محمود، تقديم: د. محيي الدين صابر، دار الجيل، بيروت-لبنان،

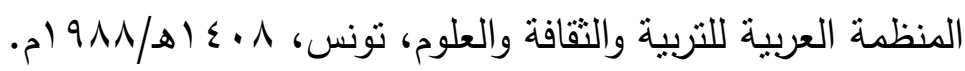
r ا القيم الإنسانية في القرآن الكريم، د. وهبة الزحيلي، دار المكتبي، دمشق-

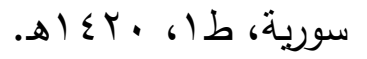

با - كتاب الأموال، حميد بن زنجويه (10 (به)، تحقيق: د.شاكر ذيب فياض، مركز

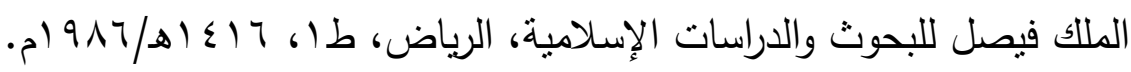




\section{النزعة الإنسانية}

ـ ا - كنز العمال في سنن الأقوال والأفعال، البرهان فوري(9 وهـه)، ضبطه وفسر

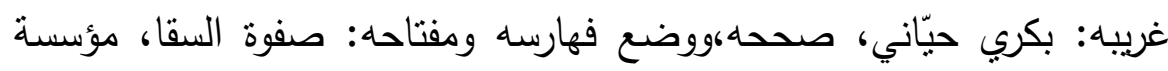

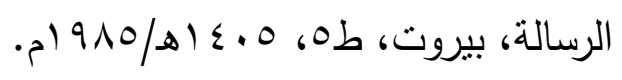

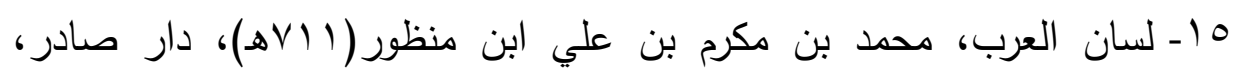

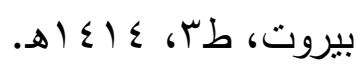

7 ا ـ مبادرة خادم الحرمين الثريفين الملك عبد الله بن عبد العزيز آل سعود للحوار

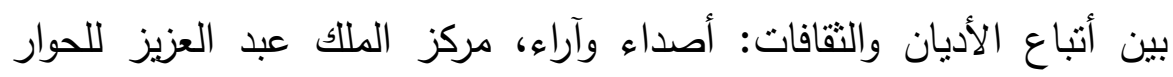

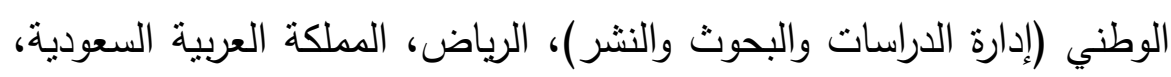

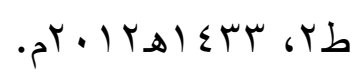

IV المسند الصحيح المختصر بنقل العدل عن العدل إلى رسول الهه صلى اله عليه

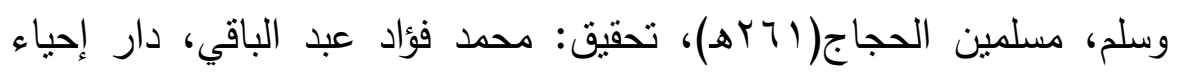

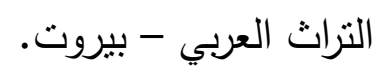

1 اـ المشترك الإنساني - نظرية جديدة للتقارب بين الثعوب-، أ.د. راغب

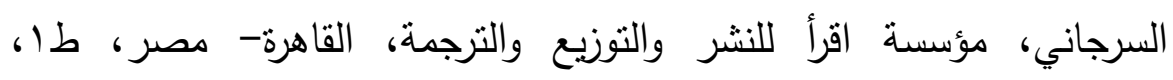

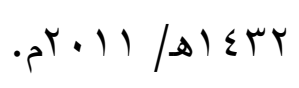

9 ا ـ مفهوم حقوق الإنسان في الفكر الإسلامي، نقلا عن حقوق الإنسان في القران

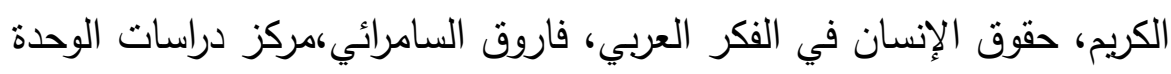

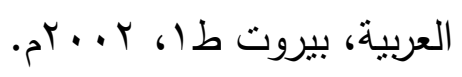

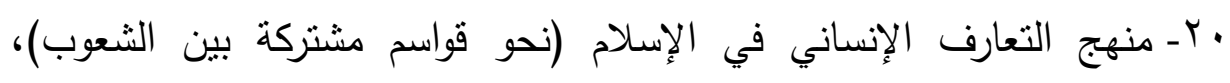

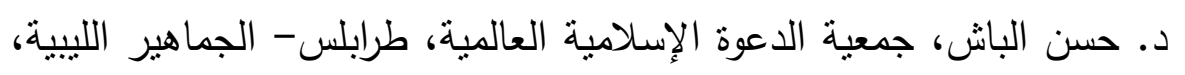

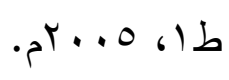




\section{د. · محمد بن عبد الواحد المسعود}

اب ـ النزعة الإسلامية في الشعر السعودي: دراسة فنية وموضوعية، د. حسن بن فهد الهويمل، الأمانة العامة للاحتفال بمرور مئة عام على تأسيس المملكة

$$
\text { العربية السعودية، } 9 \text { 1) (اهـ/999 (م. }
$$

ب- المقالات والأوراق العلمية:

ا - حماية ضحايا الحروب في الشريعة الإسلامية، أ.د. سليمان بن عبد الله أبو الخيل، مجلة الدراسات الدبلوماسية، معهد الدراسات الدبلوماسية، الرياض-

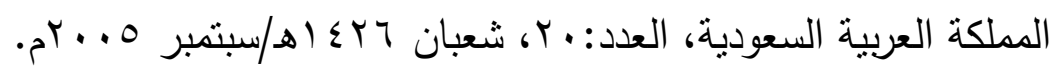
r- القيم الإنسانية في الإسلام (ورقة بحثية مقدمة إلى الندوة الدولية: "التعايش السلمي في الإسـلام "المنعقدة في (كولومبو) في (سريلانكا) في الفترة من 11 -

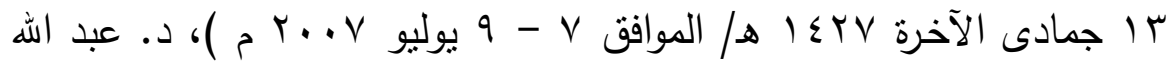
بن علي بصفر - من ب- مفهوم حقوق الإنسان في الفكر الإسلامي، أ.م.د. أمل هندي كاطع الخزعلي، جابر جواد كاظم الحمداني،مجلة مركز بابل للدراسات الإنسانية،بابل-جمهورية

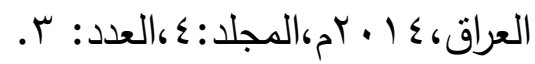

ع- هل إسرائيل دولة رفاه أو دولة فقر؟ نشرة أفق الحاسوبية؛ الصادرة عن مؤسسة

\begin{tabular}{|c|c|}
\hline رابط الموقع & ضوع \\
\hline $\begin{array}{l}\text { http://www.un.org/ar/events/tor } \\
\text { turevictimsday/assets/pdf/rro } \\
\text { PDF I.pdf }\end{array}$ & 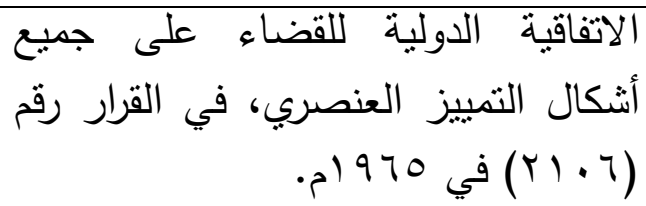 \\
\hline 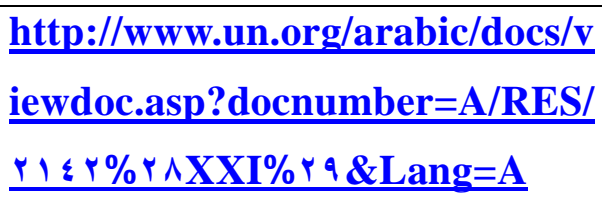 & 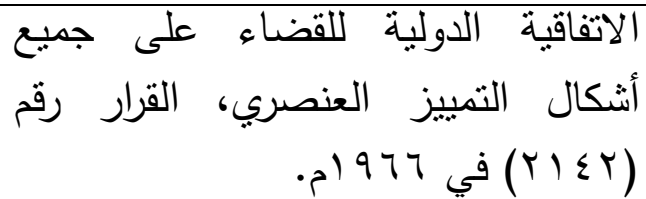 \\
\hline
\end{tabular}

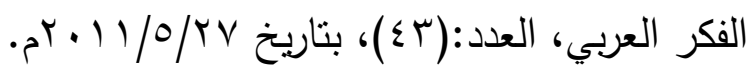




\section{النزعة الإنسانية}

\begin{tabular}{|c|c|}
\hline $\begin{array}{l}\text { http://www.un.org/ar/events/rac } \\
\text { ialdiscriminationday/documents } \\
\text { shtml }\end{array}$ & أثنال التمييز العنصري (الدولية للقضاء على جميع الوثائق). \\
\hline $\begin{array}{l}\text { http://www.un.org/ar/events/rac } \\
\text { ialdiscriminationday }\end{array}$ & العوقع الرسمي للقضاء على التمبيز \\
\hline 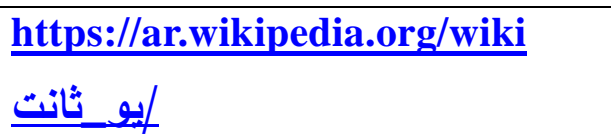 & لحرة) \\
\hline
\end{tabular}

